\title{
Regulation of hamster sperm hyperactivation by extracellular $\mathrm{Na}^{+}$
}

\author{
Gen L Takei and Masakatsu Fujinoki \\ Department of Regulatory Physiology, Dokkyo Medical University, Mibu-Machi, Tochigi, Japan \\ Correspondence should be addressed to G L Takei; Email: takei@dokkyomed.ac.jp
}

\begin{abstract}
Mammalian sperm motility has to be hyperactivated to be fertilization-competent. Hyperactivation is regulated by extracellular environment. Osmolality of mammalian semen is higher than that in female reproductive tract; however, the effect of them on hyperactivation has not been investigated. So we investigated the effect of osmotic environment on hyperactivation using hamster spermatozoa at first. Increase in the osmolality of the media $(\sim 370 \mathrm{mOsm})$ by increasing the concentration of $\mathrm{NaCl}(\sim 150 \mathrm{mmol} / \mathrm{L})$ caused the delay of the expression of hyperactivation. When $\mathrm{NaCl}$ concentration varied in the same range $(75-150 \mathrm{mmol} / \mathrm{L}) \mathrm{whereas}$ the osmolality was fixed at $370 \mathrm{mOsm}$ by adding mannitol, the delay of hyperactivation occurred dependent on $\mathrm{NaCl}$ concentration. Increase in $\mathrm{NaCl}$ concentration also caused suppression of curvilinear velocity, bend angle, and sliding velocity of the flagellum at the onset of incubation, suggesting that $\mathrm{NaCl}$ concentration affect both activation and hyperactivation in hamster spermatozoa. Hamster sperm intracellular $\mathrm{Ca}^{2+}$ concentration decreased as extracellular $\mathrm{NaCl}$ concentration increased, whereas membrane potential and intracellular $\mathrm{pH}$ were unaffected by extracellular $\mathrm{NaCl}$ concentration. SN-6 and SEA0400, inhibitors of $\mathrm{Na}^{+}-\mathrm{Ca}^{2+}$ exchanger $\left(\mathrm{NCX}^{2}\right.$, increased intracellular $\mathrm{Ca}^{2+}$ and accelerated hyperactivation in the presence of $150 \mathrm{mmol} / \mathrm{L} \mathrm{NaCl}$. Tyrosine phosphorylation on fibrous sheath proteins was unaffected by extracellular $\mathrm{NaCl}$ concentration. These results suggest that extracellular $\mathrm{Na}^{+}$suppresses hamster sperm hyperactivation by reducing intracellular $\mathrm{Ca}^{2+}$ via an action of $\mathrm{NCX}$ in a tyrosine phosphorylation-independent manner. It seems that the removal of suppression by extracellular $\mathrm{Na}^{+}$leads to the expression of hyperactivated motility.

Reproduction (2016) 151 589-603
\end{abstract}

\section{Introduction}

Mammalian spermatozoa have to undergo physiological qualitative change named "capacitation" to be able to fertilize with ovum (Yanagimachi 1994). Capacitation consists of several physiological events such as acrosome reaction and hyperactivation. The acrosome reaction is an exocytosis of acrosomal content, whereas the hyperactivation is a specialized flagellar motility characterized by increased flagellar bending with asymmetric waveform. Both the acrosome reaction and the hyperactivation are reported to be necessary for the success of fertilization in vivo and in vitro (Yanagimachi 1994, Quill et al. 2003, Ho et al. 2009, Alasmari et al. 2013). Various factors and events are reported to be associated with the regulation of capacitation (Yanagimachi 1994, Visconti \& Kopf 1998, Visconti et al. 1998, Fujinoki 2009, Fujinoki et al. 2015).

For example, capacitation/hyperactivation of mammalian spermatozoa is regulated by various ligands and hormones. In human spermatozoa, progesterone and melatonin regulate hyperactivation (du Plessis et al. 2010, Armon \& Eisenbach 2011) and acrosome reaction (Baldi et al. 2009). Such an effect of progesterone is suppressed by estrogen (Baldi et al. 2009). Gamma-aminobutyric acid (GABA) seems to increase hyperactivation in ram and human spermatozoa (Calogero et al. 1996, de las Heras et al. 1997, Ritta et al. 1998).

In hamster spermatozoa, hyperactivation is also regulated by various extracellular materials (Fujinoki 2009, Fujinoki et al. 2015). Sperm hyperactivation is enhanced by serotonin (Fujinoki 2011), melatonin (Fujinoki 2008), and progesterone (Noguchi et al. 2008), whereas enhancement of hyperactivation by progesterone is suppressed by estrogen (Fujinoki 2010) or GABA (Kon et al. 2014). The enhancement of hyperactivation by melatonin is also suppressed by estrogen (Fujinoki \& Takei 2015). These hormones are known to change during female estrous cycle (Louzan et al. 1986, Libersky \& Boatman 1995, Schillo 2009), and hyperactivation/ capacitation is suggested to be regulated by monitoring the changing environment of the oviduct (Fujinoki 2008, Coy et al. 2012). In other words, the balance between facilitative factors and suppressive factors regulates the timing of hyperactivation/capacitation to occur precisely at the time when ovum reach to the ampulla after ovulation 
(Fujinoki 2010, 2014, Kon et al. 2014, Fujinoki \& Takei 2015). As mentioned above, abundant knowledge about the enhancing or facilitating factors of hyperactivation/ capacitation already exists. However, although there are already some known factors that suppress the enhancing effect on hyperactivation, factors that suppress hyperactivation per se have not reported so far.

Meanwhile, spermatozoa of the species that undergo external fertilization, such as teleosts, activate flagellar motility in response to the drastic change of extracellular environment such as osmotic pressure and concentration of the $\mathrm{K}^{+}$(Alavi \& Cosson 2006, Takei et al. 2012, 2015). The osmolality of the fluids from mammalian male genitalia is generally higher than that of other fluids (Yeung et al. 2006). Therefore, mammalian spermatozoa also experience osmotic shock upon ejaculation under physiological condition. The cellular volume regulatory mechanisms upon ejaculation-related osmotic shock have been shown to be essential to accomplish fertilization (Yeung et al. 2006, Chen \& Duan 2011, Chen et al. 2011). However, the impact of osmotic shock on other aspects, such as motility and capacitation, has not yet been elucidated.

In this study, we first aimed to elucidate the impact of physiological osmotic shock on hamster sperm motility and hyperactivation. Then, we unexpectedly found that higher concentration of extracellular $\mathrm{Na}^{+}$ion suppressed motility and delayed hyperactivation of hamster spermatozoa. It is likely that $\mathrm{Na}^{+}-\mathrm{Ca}^{2+}$ exchanger (NCX) is involved in the regulation of hamster hyperactivation by $\mathrm{Na}^{+}$.

\section{Materials and methods}

\section{Reagents and solutions}

$\mathrm{DisC}_{3}$ (5) (3,3'-dipropylthiadicarbocyanine iodide) was from Invitrogen. Hepes, BCECF (2,7 biscarboxyethyl-5(6)carboxyfluorescein)-AM, and fluo-4 AM were from Dojindo (Kumamoto, Japan). Bovine serum albumin (BSA) fraction $\mathrm{V}$ was purchased from Merk KGaA (Darmstadt, Germany). Nagluconate was from Sigma-Aldrich. All other chemicals were purchased from Wako pure chemical.

Modified Tyrode's albumin lactate pyruvate medium (mTALP) consisted of $101 \mathrm{mmol} / \mathrm{L} \mathrm{NaCl}, 2.68 \mathrm{mmol} / \mathrm{L} \mathrm{KCl}$, $0.36 \mathrm{mmol} / \mathrm{L} \quad \mathrm{NaH}_{2} \mathrm{PO}_{4}, \quad 1.8 \mathrm{mmol} / \mathrm{L} \quad \mathrm{CaCl}_{2}, \quad 0.49 \mathrm{mmol} / \mathrm{L}$ $\mathrm{MgCl}_{2}, 35.7 \mathrm{mmol} / \mathrm{L} \mathrm{NaHCO}{ }_{3}, 4.5 \mathrm{mmol} / \mathrm{L}$ glucose, $1 \mathrm{mmol} / \mathrm{L}$ sodium pyruvate, $9.0 \mathrm{mmol} / \mathrm{L}$ lactic acid, $0.5 \mathrm{mmol} / \mathrm{L}$ hypotaurine, $0.05 \mathrm{mmol} / \mathrm{L}$ (-)epinephrine, $0.2 \mathrm{mmol} / \mathrm{L}$ sodium taurocholate, $5.26 \mu \mathrm{mol} / \mathrm{L}$ sodium metasulfate, $0.1 \mathrm{mmol} / \mathrm{L}$ EDTA, $0.05 \%(\mathrm{w} / \mathrm{v})$ penicillin $\mathrm{G}, 0.05 \%(\mathrm{w} / \mathrm{v})$ streptomycin sulfate, and $15 \mathrm{mg} / \mathrm{mL}$ BSA (Maleszewski et al. 1995). Osmotic pressure of mTALP was adjusted by changing the concentration of $\mathrm{NaCl}$ in a range of $75-150 \mathrm{mmol} / \mathrm{L}$, or by adding $50-150 \mathrm{mmol} / \mathrm{L}$ mannitol. Tyrode's lactate pyruvate medium (TLP) solution was prepared by eliminating BSA from mTALP with $150 \mathrm{mmol} / \mathrm{L} \mathrm{NaCl}$. Sucrose- $\mathrm{Ca}^{2+}$ solution consisted of $300 \mathrm{mmol} / \mathrm{L}$ sucrose, $2.65 \mathrm{mmol} / \mathrm{L} \mathrm{CaCl}_{2}$, and $10 \mathrm{mmol} / \mathrm{L}$ Hepes-NaOH, pH 7.4.

\section{Animals}

Spermatozoa and fluids of the male and female genitalia were collected from sexually matured golden hamsters (Mesocricetus auratus). Hamsters were killed by overdose of isoflurane and the male genitalia were excised by dissection. The excised organs were used as described below. All experimental animals were kept and used in accordance with the guidelines of the Dokkyo Medical University, Mibu, Tochigi, Japan, and this study was approved by the Animal Care and Use Committee of Dokkyo Medical University (Experimental permission no.: 0107).

\section{Collection of fluids and measurements of osmolality and concentration of elements}

The fluid of the seminal vesicle was directly collected by syringe and 23-gauge needle. The fluid of prostate was collected as follows: the prostate was isolated by dissection, put into $1.5 \mathrm{~mL}$ tube, and minced. After centrifugation at $5000 \mathrm{~g}$, $4^{\circ} \mathrm{C}$ for $10 \mathrm{~min}$, supernatant was used as prostatic fluid. The epididymal fluid was collected in a similar way: epididymis was isolated by dissection and punched with needles, and the epididymal content was squeezed out and collected into $0.6 \mathrm{~mL}$ tube. After centrifugation at $6340 \mathrm{~g}, 4^{\circ} \mathrm{C}$ for $10 \mathrm{~min}$, supernatant was used as epididymal fluid.

Oviductal fluid was collected from the females which were induced superovulation by intraperitoneal injection of $30 \mathrm{IU}$ pregnant mare serum gonadotropin (PMSG) and 30 IU human chorionic gonadotropin (hCG), and was collected $3-5 \mathrm{~h}$ after administration of hCG. The collection of oviductal fluid was performed as reported previously (Libersky \& Boatman 1995). Briefly, oviducts of anesthetized hamsters were cannulated according to a surgical procedure where the infundibulum of the oviduct is reflected out of the bursal sac. The cannula (Eppendorf GELoader; Eppendorf, Hamburg, Germany) was inserted through the fimbria until the tip reaches just inside the ampulla and then clamped with a nylon suture (Natsume Seisakusho, Tokyo, Japan). Both sides of oviducts were cannulated for $1 \mathrm{~h}$, and the oviductal fluid filled in the cannula was collected and used for the measurements.

Osmotic pressure of the fluids and media was determined by osmometer using depression of freezing point technique (Osmomat 030-D; Gonotec, Berlin, Germany). The concentrations of $\mathrm{Na}, \mathrm{K}$, and $\mathrm{Ca}$ (including nonionic $\mathrm{Na}, \mathrm{K}$, and $\mathrm{Ca}$ ) in the collected fluids were determined by atomic absorption supectrophotometer (Z-5300; Hitachi).

\section{Preparation and analysis of hyperactivation}

Spermatozoa were obtained from cauda epididymis. Hyperactivated spermatozoa were prepared and analyzed by the methods described previously with some modifications (Fujinoki et al. 2006). Hamsters were killed by overdose of isoflurane, and the caudal epididymis was excised. The excised cauda epididymis was punched with needle, and the epididymal spermatozoa were gently squeezed out from the epididymis. A drop of squeezed epididymal spermatozoa were put in 3.5- $\mathrm{cm}$ dish, diluted with mTALP, and incubated at $37^{\circ} \mathrm{C}$ in humid $\mathrm{CO}_{2}$ incubator $(5 \%$ $\mathrm{CO}_{2}$ and $95 \%$ air) until observation for hyperactivation to occur. 
Motility of the spermatozoa was observed by CCD camera (Progressive 3CCD; Sony, Tokyo, Japan) mounted on inverted phase-contrast microscopy (IX70; Olympus) equipped with a small $\mathrm{CO}_{2}$ incubator (MI-IBC; Olympus) and recorded on videotapes by video recorder (NV-SX10; Panasonic, Osaka, Japan). Recordings were done every $30 \mathrm{~min}$ up to $3-4 \mathrm{~h}$.

Inhibitors were dissolved in ethanol or dimethyl sulfoxide (DMSO) and added to the incubating medium at the start of the incubation. The concentration of the vehicle was fixed at $0.1 \%$ in all experiments.

Sperm motility was analyzed by manually counting the total spermatozoa, motile spermatozoa, and hyperactivated spermatozoa on slow-motion playback of the video recordings. Hyperactivation was defined as sperm motility with asymmetric and whiplash flagellar motion and a circular and/or octagonal swimming locus (Fujinoki et al. 2015). Curvilinear velocity (VCL) was determined manually by tracing the locus of the sperm head from video recordings onto the transparent plastic sheet. Beat frequency, bend angle, and sliding velocity were determined from the flagellar waveform traced manually onto transparent plastic sheet, as reported previously (Takei et al. 2014). Beat frequency was calculated from the number of video fields required to complete one beat cycle. The bend angle of the flagellum was determined by measuring the angle between the tangents at two adjacent points of inflection and then the flagellar bends reach the center of the flagellum. The angles were measured for both principal (pro-hook) and reverse (anti-hook) bends, and data were expressed as the sum of them. Sliding velocity was calculated as the product of beat frequency and bend angle (Takei et al. 2014). All the analyses were performed in the blinded way.

\section{Measurement of membrane potential}

Measurement of sperm membrane potential was performed as reported previously with slight modifications (Espinosa \& Darszon 1995, Zeng et al. 1995, Izumi et al. 1999). Briefly, caudal epididymal spermatozoa were diluted directly with mTALP to a concentration of $10^{6}-10^{7}$ cells $/ \mathrm{mL}$ in quarts cuvette. Subsequently, $1 \mu \mathrm{mol} / \mathrm{L}$ CCCP (carbonyl cyanide $m$-chlorophenylhydrazone) (final) was added to cuvette to cancel mitochondrial potential, and $1 \mu \mathrm{mol} / \mathrm{L} \operatorname{DisC}_{3}$ (5) (final) was added to cuvette and incubated for $1 \mathrm{~min}$ at room temperature. After incubation, the fluorescence at $620 \mathrm{~nm}$ excitation $/ 670 \mathrm{~nm}$ emission was measured by fluorescence spectrophotometer (F-4010; Hitachi). Subsequently, calibration of membrane potential was performed as described previously (Demarco et al. 2003) by adding $1 \mu \mathrm{mol} / \mathrm{L}$ valinomycin and then sequentially adding $2.66,2,4$, and $8 \mu \mathrm{L} 2 \mathrm{M} \mathrm{KCl}$ (corresponding to 2.68, 8, 12, 20 , and $36 \mathrm{mmol} / \mathrm{L} \mathrm{K}^{+}$respectively). Intracellular $\mathrm{K}^{+}$concentration used for the determination of membrane potential was estimated to be $90 \mathrm{mmol} / \mathrm{L}$ as reported previously (Zeng et al. 1995). The measured sperm membrane potentials correspond to those at the onset of incubation.

\section{Measurement of intracellular $\mathrm{pH}$}

Measurement of sperm intracellular $\mathrm{pH} \quad\left([\mathrm{pH}]_{\mathrm{i}}\right)$ was determined as reported previously using fluorescent dye,
BCECF (Negulescu \& Machen 1990, Takai \& Morisawa 1995). In short, spermatozoa from cauda epididymis were suspended in sucrose- $\mathrm{Ca}^{2+}$ solution containing $4 \mu \mathrm{mol} / \mathrm{L}$ BCECF-AM and incubated at $37^{\circ} \mathrm{C}, 5 \% \mathrm{CO}_{2}$ for $30 \mathrm{~min}$ to load fluorescent dye. After incubation, spermatozoa were washed by brief centrifugation and resuspended in fresh sucrose- $\mathrm{Ca}^{2+}$ solution. Washed spermatozoa were diluted ten-fold by mTALP supplemented with $20 \mathrm{mmol} / \mathrm{L}$ Hepes$\mathrm{NaOH}(\mathrm{pH} 7.4)$ containing different concentration of $\mathrm{NaCl}$, and the fluorescence was measured at both $440 \mathrm{~nm}$ and $490 \mathrm{~nm}$ excitation/single $530 \mathrm{~nm}$ emission by fluorescence spectrophotometer (F-4010; Hitachi). The $[\mathrm{pH}]_{i}$ value was calibrated by in situ calibration reported previously with slight modifications (Negulescu \& Machen 1990, Takai \& Morisawa 1995). Briefly, dye-loaded spermatozoa were suspended ten-fold in calibration solution containing $70 \mathrm{mmol} / \mathrm{L}$ K-gluconate, $20 \mathrm{mmol} / \mathrm{L} \mathrm{KCl}, 10 \mathrm{mmol} / \mathrm{L} \mathrm{NaCl}, 1 \mathrm{mmol} / \mathrm{L}$ $\mathrm{MgCl}_{2}, 10 \mathrm{mmol} / \mathrm{L}$ glucose, and $30 \mathrm{mmol} / \mathrm{L}$ Hepes $-\mathrm{KOH}$ at several values of $\mathrm{pH}(\mathrm{pH} 6.5-7.5)$ with $10 \mu \mathrm{mol} / \mathrm{L}$ nigericin. The spermatozoa suspended in calibration solution were incubated for additional $30 \mathrm{~min}$ at $37^{\circ} \mathrm{C}$, and the fluorescence was measured as described above. The calibration curve was drawn by plotting $\mathrm{pH}$ of the calibration solution against the fluorescence emission ratio of $490 / 440 \mathrm{~nm}$. The $[\mathrm{pH}]_{\mathrm{i}}$ values of the each experiment were determined from the fluorescence ratio of 490 to $440 \mathrm{~nm}$ using the calibration curve. The measured sperm $[\mathrm{pH}]_{\mathrm{i}}$ values correspond to those at the onset of incubation.

As albumin in mTALP interfered with the measurement excitation at $440 \mathrm{~nm}$, albumin in mTALP was substituted with $1 \mathrm{mg} / \mathrm{mL}$ polyvinyl alcohol (PVA) to support capacitation (Uto \& Yamahama 1996).

\section{Measurement of intracellular calcium}

Concentration of intracellular $\mathrm{Ca}^{2+}\left(\left[\mathrm{Ca}^{2+}\right]_{\mathrm{i}}\right)$ was measured with fluorescent dye, fluo-4. Caudal epididymal spermatozoa were suspended in TLP solution or sucrose-Ca ${ }^{2+}$ solution containing $4 \mu \mathrm{mol} / \mathrm{L}$ fluo-4, $2.5 \mathrm{mmol} / \mathrm{L}$ probenecid, and $0.1 \%$ Powerload and incubated for $30 \mathrm{~min}$ at $37^{\circ} \mathrm{C}, 5 \% \mathrm{CO}_{2}$ for loading the dye in hamster spermatozoa. After incubation, spermatozoa were washed by brief centrifugation and resuspended in fresh TLP or sucrose-Ca ${ }^{2+}$ solution. Washed spermatozoa were diluted 20 -fold by mTALP with different concentration of $\mathrm{NaCl}$, and fluorescence was measured at $490 \mathrm{~nm}$ excitation $/ 515 \mathrm{~nm}$ emission by fluorescence spectrophotometer (F-4010; Hitachi).

The $\left[\mathrm{Ca}^{2+}\right]_{i}$ was determined with the following equation:

$$
\mathrm{Kd} \frac{\left[F-F_{\text {min }}\right]}{\left[F_{\text {max }}-F\right]},
$$

where $F$ represents the measured fluorescence of the each experimental condition. $F_{\max }$ was the maximal fluorescence determined by addition of $0.15 \%$ triton $X-100$, and $F_{\min }$ was the minimum value of fluorescence subsequently determined by adding $9 \mathrm{mmol} / \mathrm{L}$ EGTA. The $\mathrm{Kd}$ value of 0.345 was used according to manufacturer's data sheet. The measured sperm $\left[\mathrm{Ca}^{2+}\right]_{\mathrm{i}}$ values correspond to those at the onset of incubation. 


\section{Fluorescence microscopy}

Fluorescent dye-loaded hamster spermatozoa were observed as follows. Fluorescent dyes (BCECF and fluo-4) were loaded to hamster spermatozoa as mentioned above. After loading, spermatozoa were washed as described above and diluted 100-fold in 75-150 mmol/L NaCl mTALP. An aliquot of sperm suspension was placed onto glass slide, covered with coverslip, and observed and recorded by EMCCD camera (Luca-R; Andor Technology, Belfast, UK) attached to fluorescence microscopy (IX 70; Olympus). The observation was done with 460-480 nm excitation, $490 \mathrm{~nm}$ dichroic, and $495-540 \mathrm{~nm}$ emission.

\section{Preparation of sperm fibrous sheath proteins}

Protein samples of hamster sperm fibrous sheath were prepared as follows (Fujinoki et al. 2006). Hamster spermatozoa were suspended in mTALP and incubated for an indicated time at $37^{\circ} \mathrm{C}$. After incubation, sperm suspension was centrifuged at $15,000 \mathrm{~g}$ for $10 \mathrm{~min}$ at $4^{\circ} \mathrm{C}$. Pelleted spermatozoa were suspended in urea solution consisted of $7 \mathrm{M}$ urea and $10 \% \beta$-mercaptoethanol and incubated for $10 \mathrm{~min}$ on ice. Then sperm suspension was centrifuged again at $15,000 \mathrm{~g}$ for $10 \mathrm{~min}, 4^{\circ} \mathrm{C}$. The pelleted samples were resuspended in urea-thiourea solution consisted of $5 \mathrm{M}$ urea, $1 \mathrm{M}$ thiourea, $10 \%$ $\beta$-mercaptoethanol, $10 \mathrm{mmol} / \mathrm{L}$ sodium pyrophosphate, $2 \%$ NP-40, and incubated for $10 \mathrm{~min}$ on ice. The suspension was centrifuged at $15,000 \mathrm{~g}$ for $10 \mathrm{~min}$ at $4{ }^{\circ} \mathrm{C}$, and the supernatant was used as the fibrous sheath proteins.

\section{SDS-PAGE and western blotting}

SDS-PAGE and western blotting were performed as reported previously with slight modifications (Laemmli 1970, Fujinoki et al. 2001). In short, fibrous sheath proteins prepared as mentioned above were mixed with sample buffer consisted of (final) $2.5 \%$ sodium dodecyl sulfate, $0.1 \% \beta$-mercaptoethanol, and $78 \mathrm{mmol} / \mathrm{L}$ Tris- $\mathrm{HCl} \mathrm{pH} 6.8$ and boiled for $10 \mathrm{~min}$ at $100^{\circ} \mathrm{C}$. Then boiled sample was electrophoresed in $3 \%$ polyacrylamide stacking gel and $10 \%$ polyacrylamide separating gel $(\mathrm{w} / \mathrm{v})$ and blotted to polyvinylidene fluoride membrane (Immobilon-P; Millipore). The blotted membrane was blocked by $5 \%(\mathrm{w} / \mathrm{v})$ skim milk in Tris-buffered saline (TBS) consisted of $150 \mathrm{mmol} / \mathrm{L} \mathrm{NaCl}$ and $20 \mathrm{mmol} / \mathrm{L}$ Tris- $\mathrm{HCl}$ $\mathrm{pH} 7.5$ for $1 \mathrm{~h}$ at room temperature, washed four times with TBS, and then incubated with anti-phosphotyrosine mouse monoclonal antibody (clone PT-66, 1:1000 dilution in TBS supplemented with $20 \mathrm{mg} / \mathrm{mL}$ BSA; Sigma) for $1 \mathrm{~h}$ at room temperature. After washing four times with TBS, membrane was incubated with anti-mouse IgG antibody conjugated with peroxidase $(1: 10,000$ dilution in TBS supplemented with $20 \mathrm{mg} / \mathrm{mL}$ BSA) for $1 \mathrm{~h}$ at room temperature. After washing with TBS, immunoreactive proteins were detected using $\mathrm{ECL}$ Prime Western Blotting Detection Reagent (GE Healthcare) and Ez-capture MG (ATTO, Tokyo, Japan). Densitometry analyses of the bands were done by computer software CS Analyzer 3 (ATTO; Tokyo, Japan).

\section{Statistical analysis}

Statistical analysis was done with one-way ANOVA and Tukey-Kramer post hoc test. A $P$-value $<0.05$ was considered statistically significant.

\section{Results}

\section{The osmolality and ionic composition of the fluids}

First of all, the osmolality of the fluids of the hamster male genitalia (seminal vesicle, prostate, and cauda epididymis) and female genitalia (vaginal fluid and oviductal fluid) was investigated. As summarized in Table 1, the osmolality of the fluids of seminal vesicle, prostate, and cauda epididymis was 382.2 $\pm 9.7,358.4 \pm 8.5$, and $371.4 \pm 11.5 \mathrm{mOsm}$, respectively, and was higher than that of the blood plasma $(327.2 \pm 1.7 \mathrm{mOsm})$. The significant difference between seminal vesicle fluid and blood plasma and between epididymal fluid and blood plasma was observed. The osmolality of oviductal fluid $(347.1 \pm 18.6 \mathrm{mOsm})$ was also lower than that of the fluids from male genitalia, although there were no significant differences. These results indicate that the osmolality of semen is higher than that in the other fluids such as blood plasma and oviductal fluid, as reported in other mammalians. By contrast, osmolality of the vaginal fluid $(374.0 \pm 13.9 \mathrm{mOsm})$ was almost the same as that of the fluids from male genitalia.

Then, the concentration of $\mathrm{Na}, \mathrm{K}$, and $\mathrm{Ca}$ of those fluids was measured (Table 2). The concentration of $\mathrm{Na}, \mathrm{K}$, and Ca was quite different among fluids. Na concentrations in the fluids of male genitalia (seminal vesicle, prostate, and cauda epididymis) were $51.73 \pm 1.0,50.33 \pm 2.70$, and $31.17 \pm 1.64 \mathrm{mmol} / \mathrm{L}$, respectively, and were significantly lower than that of blood plasma $(149.4 \pm 1.0 \mathrm{mmol} / \mathrm{L})$. $\mathrm{Na}$ concentration in oviductal fluid was higher $(158.79 \pm 5.76 \mathrm{mmol} / \mathrm{L})$ than that of blood plasma, although there were no significant differences between Na concentration of blood plasma and oviductal fluid.

In contrast to $\mathrm{Na}$ concentration, $\mathrm{K}$ concentration in seminal vesicle, prostate, and cauda epididymis $(60.79 \pm 1.60,46.30 \pm 3.58$, and $24.85 \pm 1.47 \mathrm{mmol} / \mathrm{L}$ respectively) was significantly higher than that of blood plasma $(6.31 \pm 0.32 \mathrm{mmol} / \mathrm{L})$. In addition, $\mathrm{K}$ concentration of oviductal fluid $(20.95 \pm 3.74 \mathrm{mmol} / \mathrm{L})$ was also significantly higher than in blood plasma.

Table 1 The osmolality of fluids from male and female genitalia.

\begin{tabular}{|c|c|c|c|c|c|c|}
\hline & Blood plasma & Seminal vesicle & Prostate & Cauda epididymis & Oviduct & Vagina \\
\hline Osmolality (mOsm) & $327.2 \pm 1.7^{a}$ & $382.2 \pm 9.7^{b}$ & $358.4 \pm 8.5^{a, b}$ & $371.4 \pm 11.5^{a, b}$ & $347.1 \pm 18.6^{a, b}$ & $374.0 \pm 13.9^{a, b}$ \\
\hline
\end{tabular}

All values are expressed in mOsm. Data are presented as mean \pm S.E.M., $n=10$ except for oviductal fluid. The osmolality value of oviductal fluid was the mean of four measurements and 7-20 hamsters were used per one measurement of oviductal fluid. The different superscript letters represent significant differences $(P<0.05)$. 
Table 2 The $\mathrm{Na}^{+}, \mathrm{K}^{+}$and $\mathrm{Ca}_{2}{ }^{+}$concentrations of fluids of male and female genitalia were measured.

\begin{tabular}{lrrrrr}
\hline & Blood plasma & Seminal vesicle & Prostate & Cauda epididymis & Oviduct \\
\hline $\mathrm{Na}(\mathrm{mmol} / \mathrm{L})$ & $149.40 \pm 0.95^{\mathrm{a}}$ & $51.73 \pm 1.05^{\mathrm{b}}$ & $50.33 \pm 2.70^{\mathrm{b}}$ & $31.17 \pm 1.64^{\mathrm{c}}$ & $158.79 \pm 5.76^{\mathrm{a}}$ \\
$\mathrm{K}(\mathrm{mmol} / \mathrm{L})$ & $6.31 \pm 0.32^{\mathrm{a}}$ & $60.79 \pm 1.60^{\mathrm{d}}$ & $46.30 \pm 3.58^{\mathrm{c}}$ & $24.85 \pm 1.47^{\mathrm{b}}$ & $20.95 \pm 1.87^{\mathrm{b}}$ \\
$\mathrm{Ca}(\mathrm{mmol} / \mathrm{L})$ & $2.36 \pm 0.09^{\mathrm{b}}$ & $0.39 \pm 0.06^{\mathrm{d}}$ & $3.08 \pm 0.20^{\mathrm{a}}$ & $0.21 \pm 0.01^{\mathrm{d}}$ & $1.42 \pm 0.16^{\mathrm{c}}$ \\
\hline
\end{tabular}

All ionic species are expressed in $\mathrm{mmol} / \mathrm{L}$. Data are presented as mean \pm S.E.M., $n=10$ except for oviductal fluid. The ionic concentration value of oviductal fluid was the mean of four measurements and 7-20 hamsters were used per one measurement of oviductal fluid. Different superscript letters represent significant differences $(P<0.05)$.

Ca concentration of caudal epididymal fluid $(0.21 \pm 0.01 \mathrm{mmol} / \mathrm{L})$ and seminal vesicle fluid $(0.39 \pm 0.06 \mathrm{mmol} / \mathrm{L})$ was significantly lower than that of blood plasma $(2.36 \pm 0.09 \mathrm{mmol} / \mathrm{L})$, prostatic fluid $(3.08 \pm 0.20 \mathrm{mmol} / \mathrm{L})$, and oviductal fluid $(1.42 \pm 0.16 \mathrm{mmol} / \mathrm{L})$.

\section{Hyperactivation was delayed when the osmolality of the media was increased by $\mathrm{NaCl}$}

To investigate the effect of seminal high osmotic pressure on hamster sperm motility and hyperactivation, we used mTALP of which osmotic pressures were adjusted to 230-370mOsm by changing the $\mathrm{NaCl}$ concentration within $75-150 \mathrm{mmol} / \mathrm{L}$. As shown in Fig. $1 \mathrm{~A}$, the percentages of motile spermatozoa were not affected when the osmotic pressure of mTALP was changed by $\mathrm{NaCl}$. By contrast, $\mathrm{VCL}$ of hamster spermatozoa at $0 \mathrm{~h}$ was significantly decreased as the osmotic pressure increased by $\mathrm{NaCl}$ (Fig. 1B). After incubation for $0.5 \mathrm{~h}$, VCL in $370 \mathrm{mOsm}$ mTALP was increased, but still significantly lower than those in 230-330 mOsm mTALP. The significant differences of VCL were disappeared when the incubation time progressed to 1 and $1.5 \mathrm{~h}$ (Fig. 1B). The appearance of hyperactivation was delayed when osmotic pressure of mTALP was increased by $\mathrm{NaCl}$ (Fig. 1C). At $1 \mathrm{~h}$, hyperactivation in $230 \mathrm{mOsm}(75 \mathrm{mmol} / \mathrm{L}$ $\mathrm{NaCl}$ ) mTALP was significantly higher than the other mTALP. At $1.5 \mathrm{~h}$, almost $50 \%$ spermatozoa in $230 \mathrm{mOsm}$ (75 mmol/L NaCl) mTALP showed hyperactivated motility, whereas nearly $0 \%$ spermatozoa showed hyperactivated motility in $370 \mathrm{mOsm}(150 \mathrm{mmol} / \mathrm{L} \mathrm{NaCl})$ mTALP. The hyperactivation in $280 \mathrm{mOsm}(101 \mathrm{mmol} / \mathrm{L}$ $\mathrm{NaCl})$ and $330 \mathrm{mOsm}(125 \mathrm{mmol} / \mathrm{L} \mathrm{NaCl})$ showed halfway value between $230 \mathrm{mOsm}$ and $370 \mathrm{mOsm}$. At $2 \mathrm{~h}$ incubation, spermatozoa in $230 \mathrm{mOsm}(75 \mathrm{mmol} / \mathrm{L}$ $\mathrm{NaCl}$ ) mTALP reached a plateau at $80 \%$, significantly higher than those in $330 \mathrm{mOsm}(125 \mathrm{mmol} / \mathrm{L} \mathrm{NaCl})$ and $370 \mathrm{mOsm}(150 \mathrm{mmol} / \mathrm{L} \mathrm{NaCl}) \mathrm{mTALP}$. At $2.5 \mathrm{~h}$ incubation, hyperactivation in $370 \mathrm{mOsm}(150 \mathrm{mmol} / \mathrm{L}$ $\mathrm{NaCl}$ ) mTALP was still lower than the other mTALPs. At $3 \mathrm{~h}$ incubation, there were no differences in hyperactivation among the various osmotic pressures.

To examine whether extracellular $\mathrm{NaCl}$ affects motility parameters other than VCL and hyperactivation, we measured the time-course change of flagellar movement (beat frequency, bend angle, sliding velocity, and waveform). The results are shown in Fig. 2. Overall, beat frequency was slightly increased at $0.5 \mathrm{~h}$ of incubation and gradually decreased as incubation time progressed (Fig. 2A). When osmotic pressure was changed by $\mathrm{NaCl}$, beast frequency was increased as the osmotic pressure increased by $\mathrm{NaCl}$, highest in $330 \mathrm{mOsm}(125 \mathrm{mmol} / \mathrm{L} \mathrm{NaCl}) \mathrm{mTALP}$ and lowest in $230 \mathrm{mOsm}(75 \mathrm{mmol} / \mathrm{L} \mathrm{NaCl}) \mathrm{mTALP}$ (Fig. 2A). The beat frequency remained significantly higher at 1 and $1.5 \mathrm{~h}$ incubation in the 330 and 370 mOsm (125 and $150 \mathrm{mmol} / \mathrm{L} \mathrm{NaCl}$ ) mTALP. At 2 and $2.5 \mathrm{~h}$ of incubation, beat frequency was decreased to approximately $9 \mathrm{~Hz}$ and almost unchanged among all conditions.

Bend angle of the flagellum was lower at the onset of incubation and gradually increased as incubation time progressed, as a whole (Fig. 2B). When osmotic pressure was changed by $\mathrm{NaCl}$, bend angle was decreased as osmotic pressure of the mTALP was increased by $\mathrm{NaCl}$, i.e., largest in $230 \mathrm{mOsm}(75 \mathrm{mmol} / \mathrm{L} \mathrm{NaCl}) \mathrm{mTALP}$ and smallest in $370 \mathrm{mOsm}(150 \mathrm{mmol} / \mathrm{L} \mathrm{NaCl}) \mathrm{mTALP}$ (Fig. 2B). The difference of bend angle was most prominent at the onset of incubation and gradually reduced as incubation time progressed. Finally, no difference in bend angle was observed among all conditions at 2 and $2.5 \mathrm{~h}$ of incubation (Fig. 2B). When we looked at principal bend and reverse bend separately, both principal and reverse bend increased dependent on time (Fig. 2C and D). Higher osmotic pressure by $\mathrm{NaCl}$ suppressed both principal and reverse bend at the onset of incubation. The difference of bend angle was gradually reduced as incubation time progressed (at $0.5-1.5 \mathrm{~h}$ of incubation). At $2 \mathrm{~h}$ of incubation, no difference in principal bend was observed among 230-370 mOsm $(75-150 \mathrm{mmol} / \mathrm{L}$ $\mathrm{NaCl})$ mTALP, whereas reverse bend was still significantly lower in $370 \mathrm{mOsm}(150 \mathrm{mmol} / \mathrm{L} \mathrm{NaCl}) \mathrm{mTALP}$ when compared with 230 and $280 \mathrm{mOsm}(75$ and $101 \mathrm{mmol} / \mathrm{L}$ $\mathrm{NaCl}$ ) mTALP (Fig. 2C and D). There was no difference in reverse bend at $2.5 \mathrm{~h}$ of incubation among all conditions (Fig. 2D).

As a whole, sliding velocity was lower at the onset of incubation and gradually increased as incubation time progressed (Fig. 2E). When osmotic pressure was changed by $\mathrm{NaCl}$, sliding velocity was suppressed as osmotic pressure increased by $\mathrm{NaCl}$ at $0 \mathrm{~h}$, highest in $230 \mathrm{mOsm}(75 \mathrm{mmol} / \mathrm{L} \mathrm{NaCl}) \mathrm{mTALP}$, and lowest in $370 \mathrm{mOsm}(150 \mathrm{mmol} / \mathrm{L} \mathrm{NaCl})$ mTALP (Fig. 2E). The suppression of sliding velocity by osmotic pressure was reduced as incubation time progressed at $0.5-1 \mathrm{~h}$, and significant difference was disappeared at $1.5 \mathrm{~h}$ of incubation and thereafter (Fig. 2E). 

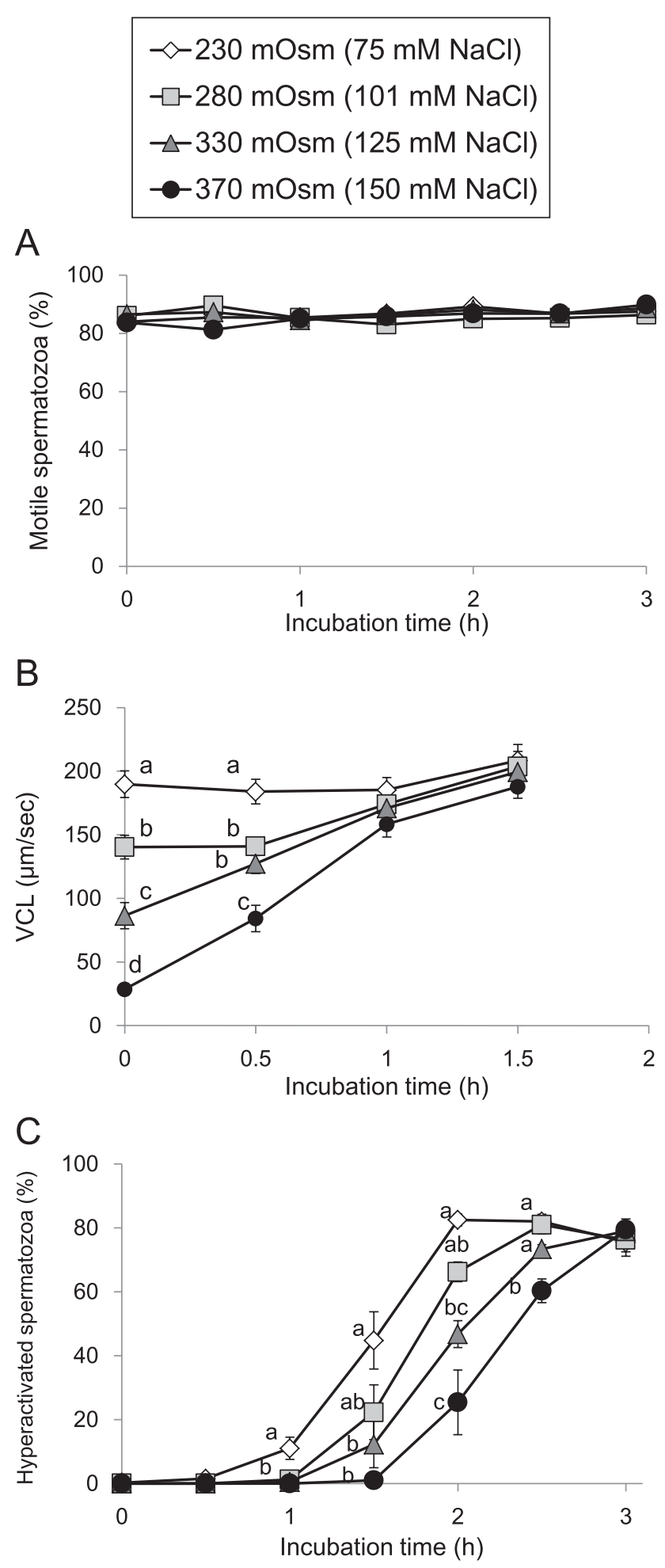

Figure 1 The effect of the difference of osmolality adjusted by $\mathrm{NaCl}$ on hyperactivation and motility of hamster spermatozoa. The effect of osmotic pressure of media on percentage of motile sperm (A),

curvilinear velocity $(\mathrm{VCL} ; \mathrm{B})$, and hyperactivation $(\mathrm{C})$ was examined using mTALP whose osmotic pressure was adjusted to $230-370 \mathrm{mOsm}$ by $75-150 \mathrm{mmol} / \mathrm{L} \mathrm{NaCl}$. Data are expressed as mean \pm S.E.M., $n=4$ (A) and (C). (B) VCL value was determined as the mean of 24 sperm cells from four males. The different superscript letters represent significant differences among them $(P<0.05)$.

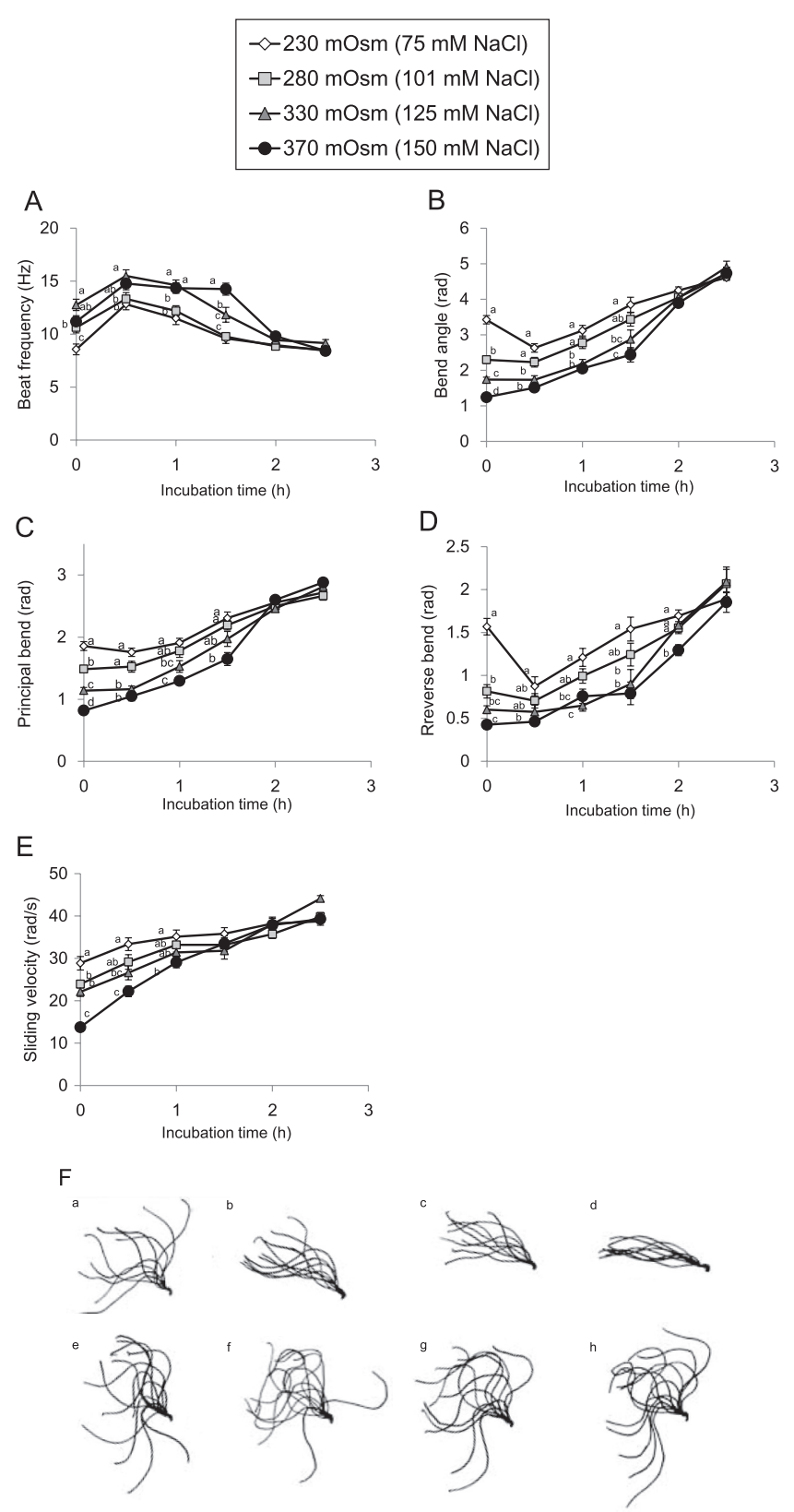

Figure 2 The effect of the difference of osmolality adjusted by $\mathrm{NaCl}$ on flagellar movement of hamster spermatozoa. The effect of osmotic pressure of media on beat frequency (A), bend angle (B), bend angle of principal bend $(C)$, reversed bend $(D)$, sliding velocity $(E)$, and flagellar waveform $(F)$ was examined in the same condition as in Fig. 1. (A, B, C, D and E) Values were determined as the mean of 15 sperm cells from three males. The different superscript letters represent significant differences among them $(P<0.05)$. (F) Flagellar waveforms in $230 \mathrm{mOsm}(75 \mathrm{mmol} / \mathrm{L} \mathrm{NaCl})(\mathrm{a}, \mathrm{e}), 280 \mathrm{mOsm}$ $(101 \mathrm{mmol} / \mathrm{L} \mathrm{NaCl})(\mathrm{b}, \mathrm{f}), 330 \mathrm{mOsm}(125 \mathrm{mmol} / \mathrm{L} \mathrm{NaCl})(\mathrm{c}, \mathrm{g})$, and $370 \mathrm{mOsm}(150 \mathrm{mmol} / \mathrm{L} \mathrm{NaCl})(\mathrm{d}, \mathrm{h}) \mathrm{mTALP}$ at $0 \mathrm{~h}(\mathrm{a}-\mathrm{d}$; activated) and at $2.5 \mathrm{~h}$ (e-h; hyperactivated) were traced for three beat cycle.

Waveform of hamster spermatozoa at $0 \mathrm{~h}$ (activated) and $2.5 \mathrm{~h}$ (hyperactivated) was shown in Fig. 2F. At $0 \mathrm{~h}$ of incubation, activated spermatozoa showed considerable change in beat amplitude (Fig. 2F a-d). In 230 mOsm 

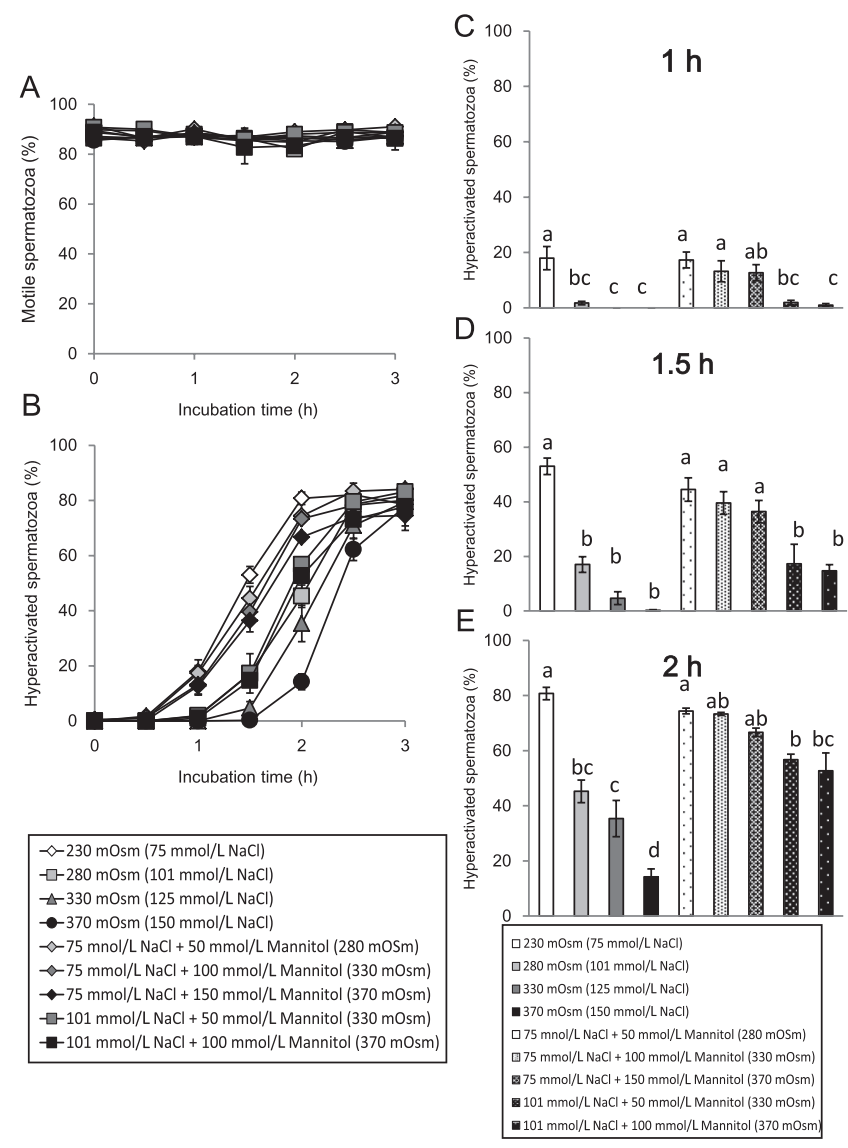

Figure 3 The effect of the difference of osmolality changed by $\mathrm{NaCl}$ and mannitol on hyperactivation of hamster spermatozoa. The effect of osmolality and $\mathrm{NaCl}$ concentration on the percentage of motile spermatozoa (A) and hyperactivation (B, C, D and E) is shown. (B) Time-course change of hyperactivation and (C, D and $\mathrm{E})$ percentage of hyperactivation at $1,1.5$, and $2 \mathrm{~h}$ respectively. Data are expressed as mean \pm S.E.M., $n=4$. The different superscript letters represent significant differences among them.

(75 mmol/L NaCl) mTALP, spermatozoa showed fairly large amplitude (Fig. $2 \mathrm{~F}$ a). Increase in osmotic pressure by $\mathrm{NaCl}$ caused narrowing of the wave amplitude, and narrowest in $370 \mathrm{mOsm}(150 \mathrm{mmol} / \mathrm{L} \mathrm{NaCl}) \mathrm{mTALP}$ (Fig. 2F b-d). When hyperactivated, hamster spermatozoa exhibited almost the same waveforms in all $\mathrm{NaCl}$ concentrations (Fig. 2F e-h).

\section{The delay of hyperactivation was caused by the increase in extracellular $\mathrm{NaCl}$}

We next investigated the effect of $\mathrm{NaCl}$ concentrations and osmotic pressure on hyperactivation by using mTALP of which $\mathrm{NaCl}$ concentrations varied from 75 to $150 \mathrm{mmol} / \mathrm{L}$, whereas osmotic pressure was fixed at 330 or 370 mOsm by mannitol.

The results are shown in Fig. 3. The percentages of motile spermatozoa were unaffected when the concentration of $\mathrm{NaCl}$ and mannitol was changed (Fig. 3A). Hyperactivation of hamster spermatozoa was delayed as $\mathrm{NaCl}$ concentration of the media was increased (Fig. 3B), as is shown in Fig. 1. When the osmotic pressure was set to $370 \mathrm{mOsm}$ by adding mannitol, however, hamster sperm hyperactivation was considerably differed depending on the concentration of $\mathrm{NaCl}$ (Fig. 3B, C, D and E). At 1 and $1.5 \mathrm{~h}$ of incubation, hyperactivation was significantly higher in mTALP containing $75 \mathrm{mmol} / \mathrm{L} \mathrm{NaCl}(75 \mathrm{mmol} / \mathrm{L} \mathrm{NaCl}$, $75 \mathrm{mmol} / \mathrm{L} \quad \mathrm{NaCl}+50 \mathrm{mmol} / \mathrm{L}$ mannitol, $75 \mathrm{mmol} / \mathrm{L}$ $\mathrm{NaCl}+100 \mathrm{mmol} / \mathrm{L}$ mannitol, and $75 \mathrm{mmol} / \mathrm{L}$ $\mathrm{NaCl}+150 \mathrm{mmol} / \mathrm{L}$ mannitol) than those in mTALP containing higher concentrations of $\mathrm{NaCl}$, regardless of the osmotic pressure of the mTALP (Fig. 3C and D). No significant differences were observed among mTALPs containing $75 \mathrm{mM} \mathrm{NaCl}$ (Fig. 3C and D). At $2 \mathrm{~h}$ of incubation, hyperactivation in mTALP containing $75 \mathrm{mmol} / \mathrm{L}$ $\mathrm{NaCl}$ was higher than that in mTALP containing 101 - $150 \mathrm{mM} \mathrm{NaCl}$, although significant differences were not observed in some cases (Fig. 3E). In addition, there was no significant difference in hyperactivation among mTALP containing $101 \mathrm{mmol} / \mathrm{L} \mathrm{NaCl}$ with different concentrations of mannitol at $1,1.5$, and $2 \mathrm{~h}$ of incubation $(101 \mathrm{mmol} / \mathrm{L} \mathrm{NaCl}, 101 \mathrm{mmol} / \mathrm{L} \mathrm{NaCl}+50 \mathrm{mmol} / \mathrm{L}$ mannitol, and $101 \mathrm{mmol} / \mathrm{L} \mathrm{NaCl}+100 \mathrm{mmol} / \mathrm{L}$ mannitol; Fig. 3C, D and E). These results suggest that delay of hamster sperm hyperactivation was caused dependently on $\mathrm{NaCl}$ concentration, but not osmolality of the media.

To examine the effect of $\mathrm{Cl}^{-}$concentration on hamster sperm hyperactivation, we used mTALP in which $\mathrm{Cl}^{-}$concentrations varied, whereas $\mathrm{Na}^{+}$concentration was fixed by a combination of Na-gluconate and $\mathrm{NaCl}$ (Supplementary Figure 1, see section on supplementary data given at the end of the article). The results showed that the decrease of $\mathrm{Cl}^{-}$by substituting it with gluconate caused further delay of the appearance of hyperactivation than $150 \mathrm{mmol} / \mathrm{L} \mathrm{NaCl}$ mTALP (Supplementary Figure 1B). We also tested mTALP where $\mathrm{Na}^{+}$concentrations varied whereas $\mathrm{Cl}^{-}$concentration was fixed by a combination of $\mathrm{NaCl}$ and choline chloride or $\mathrm{NaCl}$ and $\mathrm{N}$-methyl-D-glucamin (NMDG)-Cl (Supplementary Figure 2). However, substitution of $\mathrm{Na}^{+}$with choline ${ }^{+}$ significantly suppressed hyperactivation (Supplementary Figure 2B). In addition, the replacement of $\mathrm{Na}^{+}$with $\mathrm{NMDG}^{+}$caused significant alteration of the percentage of motile spermatozoa (Supplementary Figure 2C).

\section{Extracellular $\mathrm{Na}^{+}$did not alter the membrane potential or intracellular $\mathrm{pH}$ of hamster spermatozoa}

The effect of extracellular $\mathrm{Na}^{+}$on hamster sperm membrane potentials and intracellular $\mathrm{pH}\left(\mathrm{pH}_{\mathrm{i}}\right)$ was investigated using fluorescent dye, $\operatorname{DisC}_{3}(5)$ and BCECF (Fig. 4). The membrane potential of hamster spermatozoa was $-75.4 \pm 2.1 \mathrm{mV}$ in standard mTALP, which contains $101 \mathrm{mmol} / \mathrm{L} \mathrm{NaCl}$ (Fig. 4A). The alteration of $\mathrm{NaCl}$ concentration in mTALP did not cause significant change in hamster sperm membrane potential (Fig. 4A). Hamster 
A

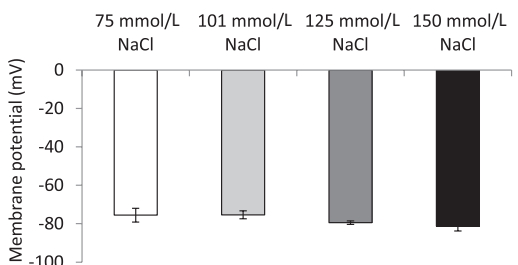

B

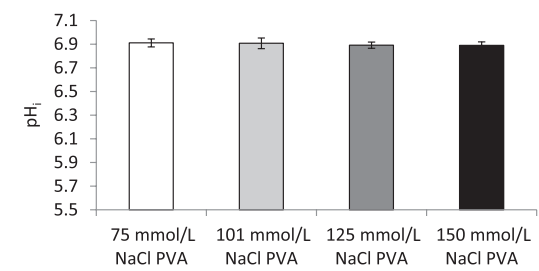

C

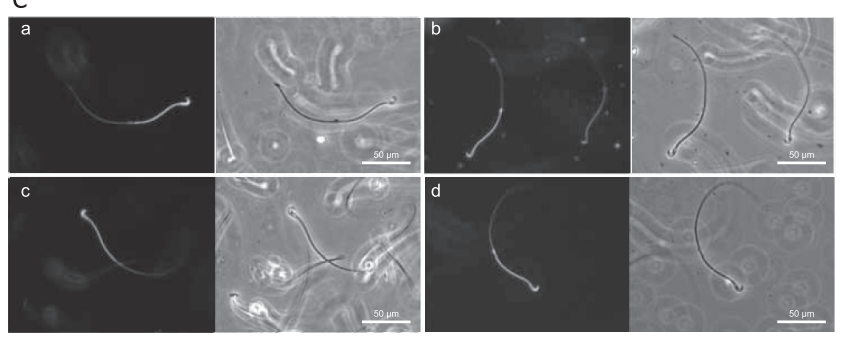

Figure 4 The effect of $\mathrm{NaCl}$ on hamster sperm membrane potential and $\mathrm{pH}_{\mathrm{i}}$ was examined by fluorescent dye $\mathrm{DisC}_{3}(5)$ and $\mathrm{BCECF}$ respectively. The determined value of membrane potentials $(\mathrm{A}), \mathrm{pH}_{\mathrm{i}}$ (B), and fluorescent picture of BCECF-loaded spermatozoa in mTALP with various concentrations of $\mathrm{NaCl}(\mathrm{C})$ was shown. (C) a, $75 \mathrm{mmol} / \mathrm{L}$ $\mathrm{NaCl}$; b, $101 \mathrm{mmol} / \mathrm{L} \mathrm{NaCl}$; c, $125 \mathrm{mmol} / \mathrm{L} \mathrm{NaCl}$; and d, $150 \mathrm{mmol} / \mathrm{L}$ $\mathrm{NaCl}$. Left panels are fluorescent images and right panels are bright-field images. There was no significant difference among all the conditions tested. Data are expressed as mean \pm S.E.M., $n=6$ in membrane potential and $n=4$ in $\mathrm{pH}_{\mathrm{i}}$.

sperm $\mathrm{pH}_{\mathrm{i}}$ was $6.91 \pm 0.06$ in standard mTALP $(101 \mathrm{mmol} / \mathrm{L}$ $\mathrm{NaCl}$ ), whereas BSA was substituted with $1 \mathrm{mg} / \mathrm{mL}$ PVA (Fig. 4B). The alteration of $\mathrm{NaCl}$ concentration in mTALP did not cause significant change in hamster sperm $\mathrm{pH}_{\mathrm{i}}$ (Fig. 4B). When BCECF-loaded spermatozoa were observed by fluorescence microscopy, the entire region of hamster sperm was fluorescent, prominent in head and midpiece, while rather faint in principal piece (Fig. 4C). No apparent difference was observed when extracellular $\mathrm{NaCl}$ concentration was changed (Fig. $4 \mathrm{C}$ a-d). When $\mathrm{pH}_{\mathrm{i}}$ was determined using mTALP containing BSA, $\mathrm{pH}_{\mathrm{i}}$ was calculated as 5.6-5.7 because of the high fluorescence at $440 \mathrm{~nm}$ excitation caused by BSA (Supplementary Figure 3). However, there was no difference in hamster sperm $\mathrm{pH}_{\mathrm{i}}$ when the concentration of $\mathrm{NaCl}$ in mTALP varied from 75 to $150 \mathrm{mmol} / \mathrm{L}$ (Supplementary Figure 3).

\section{Hamster sperm intracellular $\mathrm{Ca}^{2+}$ concentration increased as the extracellular $\mathrm{NaCl}$ concentration decreased}

The effect of extracellular $\mathrm{Na}^{+}$on hamster sperm intracellular $\mathrm{Ca}^{2+}$ concentration $\left(\left[\mathrm{Ca}^{2+}\right]_{\mathrm{i}}\right)$ was investigated by fluorescent dye, fluo- 4 . The results are shown in
Fig. 5. The $\left[\mathrm{Ca}^{2+}\right]_{i}$ value was expressed as the ratio to the fluorescence value of $75 \mathrm{mmol} / \mathrm{L} \mathrm{NaCl}$. Hamster sperm $\left[\mathrm{Ca}^{2+}\right]_{i}$ was decreased as the extracellular $\mathrm{Na}^{+}$ concentration increased (Fig. 5A). Significant differences were observed between 75 and $125 \mathrm{mmol} / \mathrm{L} \mathrm{NaCl}$, and between 75 and $150 \mathrm{mmol} / \mathrm{L} \mathrm{NaCl}$ (Fig. 5A). Similar results were obtained when fluo-4 was loaded into sperm cells in sucrose- $\mathrm{Ca}^{2+}$ solution (Supplementary Figure 4).

When fluo-4-loaded spermatozoa were observed by fluorescence microscopy, a strong fluorescence was observed in acrosome in all conditions (Fig. 5B a-d). In addition, midpiece and principal piece were also fluorescent in 75 and $101 \mathrm{mmol} / \mathrm{L} \mathrm{NaCl}$ mTALP (Fig. 5B a and $b$ ), whereas no fluorescent in flagella was observed in 125 and $150 \mathrm{mmol} / \mathrm{L} \mathrm{NaCl} \mathrm{mTALP}$ (Fig. 5B c and d).

\section{The NCX inhibitors abolished the delay of hyperactivation by high concentration of $\mathrm{Na}^{+}$}

Decrease in intracellular $\mathrm{Ca}^{2+}$ by increase in extracellular $\mathrm{Na}^{+}$let us think that $\mathrm{NCX}$ is involved in the regulation of hamster sperm hyperactivation (Fig. 5). To examine this possibility, we investigated the effect of NCX inhibitors (SN-6, SEA0400, and KB-R7943) on hyperactivation and flagellar movement in $150 \mathrm{mmol} / \mathrm{L}$ $\mathrm{NaCl}$ mTALP. The results are shown in Figs 6 and 7 . SN-6 and SEA0400 did not affect the percentage of motile spermatozoa up to $50 \mu \mathrm{mol} / \mathrm{L}$ (Fig. 6A and D). By contrast, the percentage of motile spermatozoa was significantly decreased by $50 \mu \mathrm{mol} / \mathrm{L}$ KB-R7943 at 0 ,

A

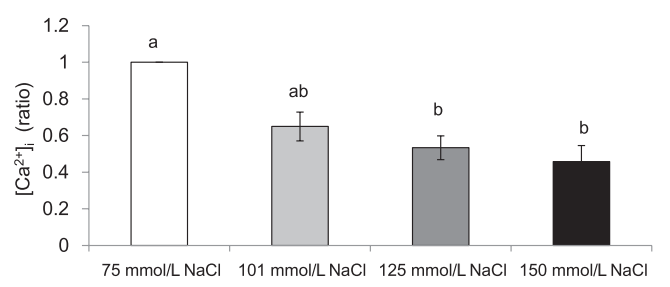

B

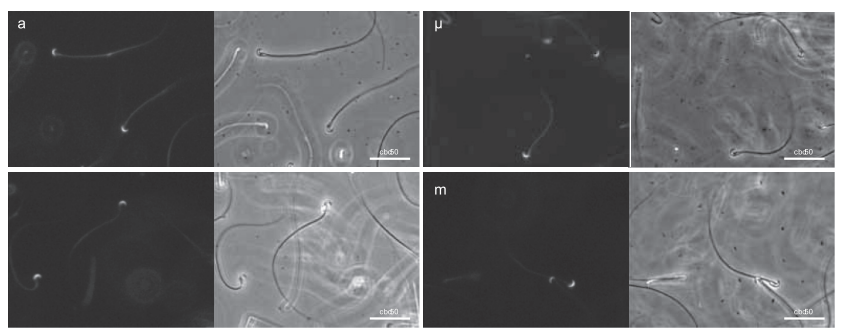

Figure 5 The effect of extracellular $\mathrm{NaCl}$ on hamster sperm intracellular $\mathrm{Ca}^{2+}$ concentration $\left(\left[\mathrm{Ca}^{2+}\right]_{\mathrm{i}}\right)$. The effect of $\mathrm{NaCl}$ on hamster sperm $\left[\mathrm{Ca}^{2+}\right]_{i}$ was examined by fluorescent dye fluo-4. (A) The determined values of $\left[\mathrm{Ca}^{2+}\right]_{i}$ by extracellular $\mathrm{Na}^{+}$. Data are expressed as the ratio to the value of $75 \mathrm{mmol} / \mathrm{L} \mathrm{NaCl} \mathrm{mTALP}$. The different superscript letters represent significant difference $(P<0.05)$. Data are expressed as mean \pm S.E.M., $n=11$. (B) The fluorescent pictures of fluo-4-loaded spermatozoa in MTALP with various concentrations of $\mathrm{NaCl}(\mathrm{a}, 75 \mathrm{mmol} / \mathrm{L} \mathrm{NaCl} ; \mathrm{b}, 101 \mathrm{mmol} / \mathrm{L} \mathrm{NaCl}$; , $125 \mathrm{mmol} / \mathrm{L} \mathrm{NaCl} ; \mathrm{d}, 150 \mathrm{mmol} / \mathrm{L} \mathrm{NaCl}$ ). Left panels are fluorescent images and right panels are bright-field images. 
A
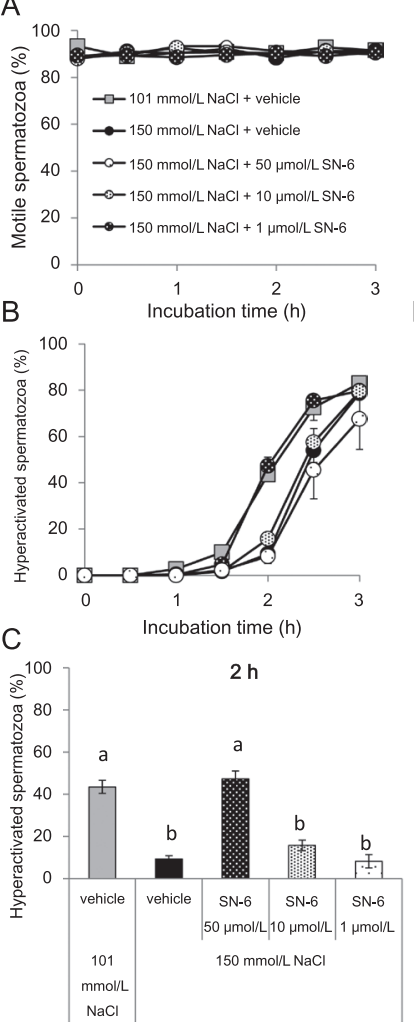

$\mathrm{D}$

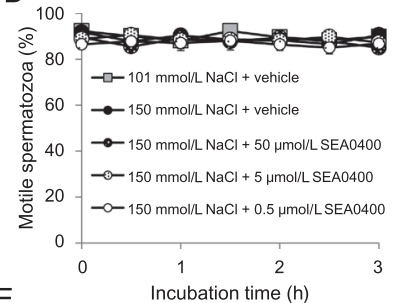

E

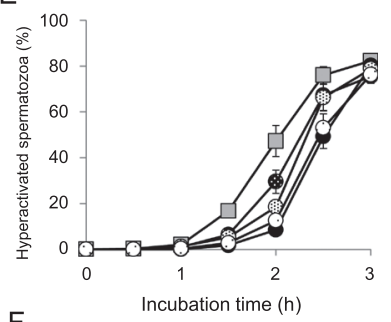

$\mathrm{F}$

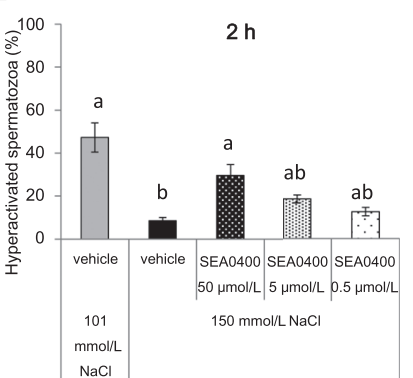

Figure 6 The effect of NCX inhibitors on hyperactivation of hamster spermatozoa. The effects of NCX inhibitors (A, B and C: SN-6, D, E and F: SEA0400) on percentage of motile sperm (A and D) and time-course change of hyperactivation $(\mathrm{B}$ and $\mathrm{E})$ and hyperactivation at $2 \mathrm{~h}(\mathrm{C}$ and $\mathrm{F}$ ) in $150 \mathrm{mmol} / \mathrm{L} \mathrm{NaCl} \mathrm{mTALP}$ are shown. Vehicle was ethanol and DMSO (1:1), and the final concentration of vehicle was set to $0.1 \%$. The different superscript letters represent significant difference $(P<0.05)$. Data are expressed as mean \pm S.E.M., $n=4$.

$0.5,1.5$, and $2.5 \mathrm{~h}$ of incubation when compared with controls (Supplementary Figure 5A).

Hyperactivation was significantly delayed in mTALP containing $150 \mathrm{mmol} / \mathrm{L} \mathrm{NaCl}$ than in mTALP containing $101 \mathrm{mmol} / \mathrm{L} \mathrm{NaCl}$, as shown in Figs 1 and 3 (Fig. 6B and $\mathrm{C}$ ). When SN-6 was added to mTALP containing $150 \mathrm{mmol} / \mathrm{L} \mathrm{NaCl}, \mathrm{SN}-6$ dose dependently canceled the suppression of hyperactivation (Fig. 6B and C). At $2 \mathrm{~h}$ of incubation, hyperactivation in $101 \mathrm{mmol} / \mathrm{L} \mathrm{NaCl}$ mTALP was significantly higher than that in $150 \mathrm{mmol} / \mathrm{L}$ $\mathrm{NaCl}$ mTALP (Fig. 6C). Addition of $50 \mu \mathrm{mol} / \mathrm{L} \mathrm{SN}-6$ to $150 \mathrm{mmol} / \mathrm{L} \mathrm{NaCl} \mathrm{mTALP} \mathrm{significantly} \mathrm{increased} \mathrm{hamster}$ sperm hyperactivation compared with $150 \mathrm{mmol} / \mathrm{L}$ $\mathrm{NaCl}+$ vehicle (Fig. 6C).

SEA0400, another inhibitor of NCX, had similar effect on hamster sperm hyperactivation (Fig. 6D, E and F). Hamster sperm hyperactivation in $150 \mathrm{mmol} / \mathrm{L} \mathrm{NaCl}$ mTALP was accelerated by SEA0400 compared with vehicle in a dose-dependent manner, and $50 \mu \mathrm{mol} / \mathrm{L}$ SEA0400 in $150 \mathrm{mmol} / \mathrm{L} \mathrm{NaCl}$ mTALP significantly increased hyperactivation than vehicle in $150 \mathrm{mmol} / \mathrm{L}$

$\mathrm{NaCl}$ mTALP at $2 \mathrm{~h}$ of incubation (Fig. 6E and F). KB-R7943 showed similar tendency with two other NCX inhibitors to accelerate hyperactivation in a dosedependent manner; however, there were no significant changes in hyperactivation by KB-R7943 (Supplementary Figure 5B).

Hamster sperm $\left[\mathrm{Ca}^{2+}\right]_{i}$ was significantly increased by $50 \mu \mathrm{mol} / \mathrm{L} \mathrm{SN}-6$ and $50 \mu \mathrm{mol} / \mathrm{L}$ SEA0400 compared with
A

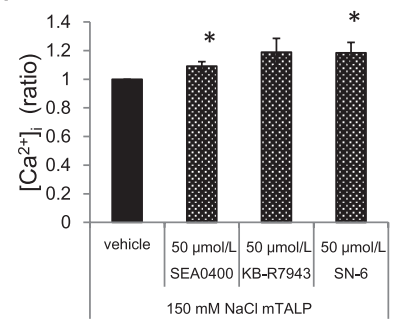

B

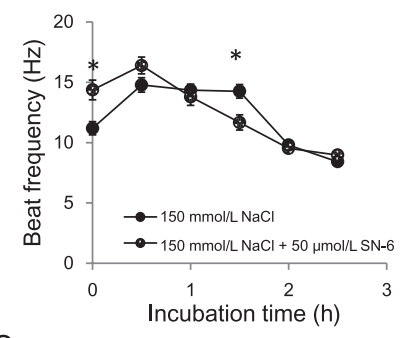

C

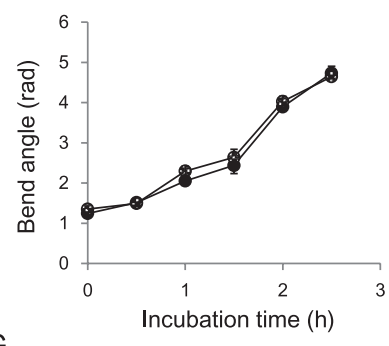

D

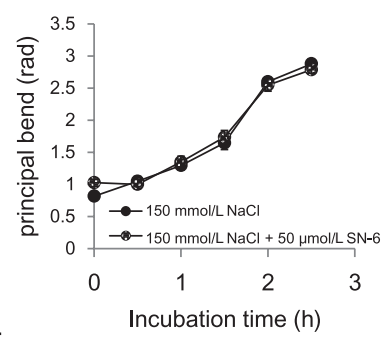

$E$

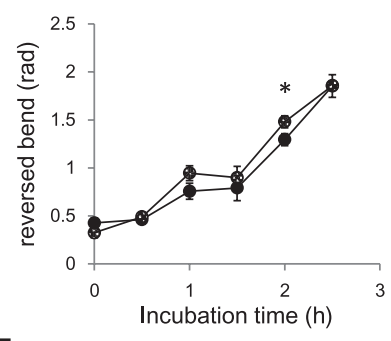

$\mathrm{F}$

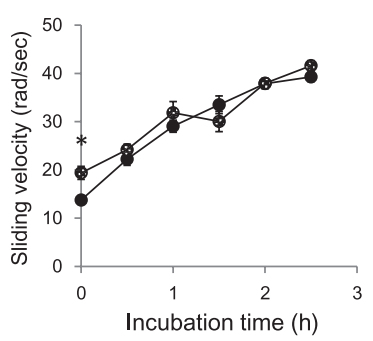

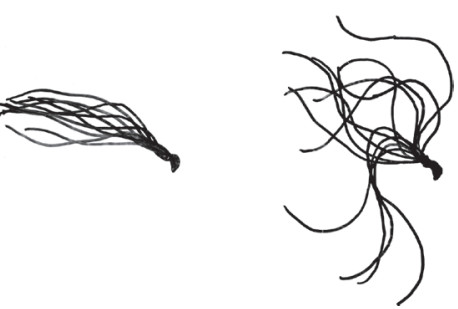

Figure 7 The effect of NCX inhibitors on $\left[\mathrm{Ca}^{2+}\right]_{i}$ and flagellar movement of hamster spermatozoa. The effects of $50 \mu \mathrm{mol} / \mathrm{L} \mathrm{SN}-6$ (A, B, C, D, E and F), $50 \mu \mathrm{mol} / \mathrm{L}$ SEA0400 (A), and $50 \mu \mathrm{mol} / \mathrm{L}$ KB-R7943 (A) on $\left[\mathrm{Ca}^{2+}\right]_{i}(A)$ beat frequency $(B)$, bend angle (C), principal bend $(D)$, reverse bend $(E)$, sliding velocity $(F)$, and waveform (G) in $150 \mathrm{mmol} / \mathrm{L} \mathrm{NaCl} \mathrm{mTALP}$ are shown. $\left[\mathrm{Ca}^{2+}\right]_{i}$ data are represented as ratio to the value of $150 \mathrm{mmol} / \mathrm{L} \mathrm{NaCl}+$ vehicle. Data are expressed as mean \pm S.E.M., $n=4(50 \mu \mathrm{mol} / \mathrm{L} \mathrm{SN}-6)$ and $n=7$ (the others) in (A). In (B, C, D, E and F), values were determined as the mean of 15 sperm cells from three males. Asterisks indicate significant difference compared with vehicle $(P<0.05)$. (G) Flagellar waveforms in $150 \mathrm{mmol} / \mathrm{L} \mathrm{NaCl} \mathrm{mTALP}$ with $50 \mu \mathrm{mol} / \mathrm{L} \mathrm{SN}-6$ at $0 \mathrm{~h}$ (a, activated) and at $2.5 \mathrm{~h}$ (b, hyperactivated) traced for three beat cycle were shown. 


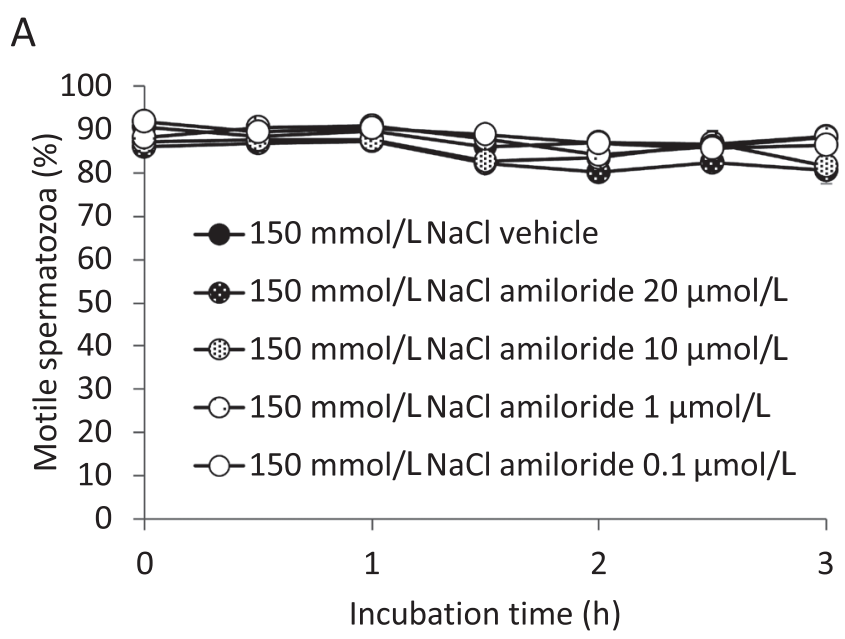

B

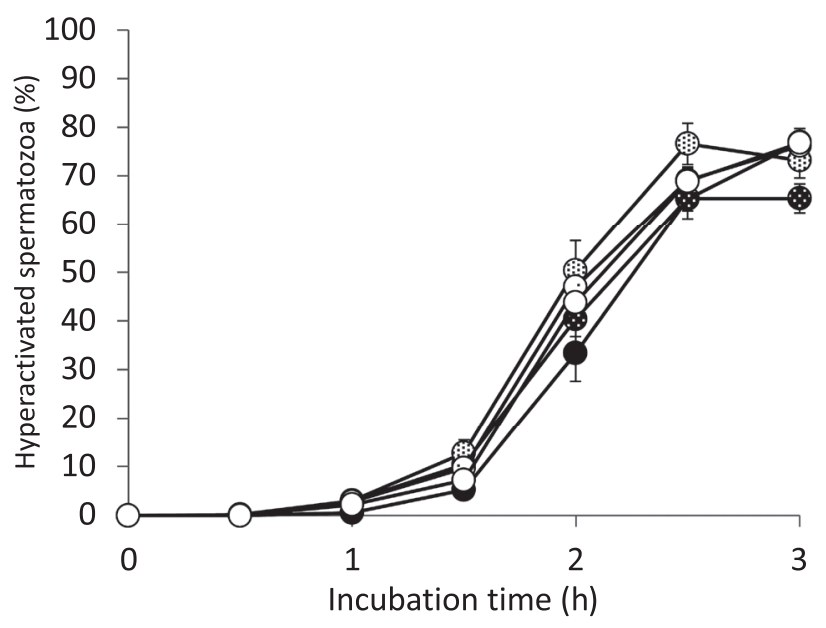

Figure 8 The effect of amiloride on hamster sperm hyperactivation. The effects of amiloride, an inhibitor of $\mathrm{ENaC}$, on the percentage of motile spermatozoa (A) and hyperactivation (B) are shown. Vehicle was distilled water, and the concentration of the vehicle was set to $0.1 \%$. There was no significant difference at all the concentration tested. Data are expressed as mean \pm S.E.M., $n=4$.

vehicle (Fig. 7A). KB-R7943 at $50 \mu \mathrm{mol} / \mathrm{L}$ also increased $\left[\mathrm{Ca}^{2+}\right]_{1}$; however, there were no significant differences between $50 \mu \mathrm{mol} / \mathrm{L} \mathrm{KB-R7943} \mathrm{and} \mathrm{vehicle} \mathrm{(Fig.} \mathrm{7A).}$

Inhibition of NCX by $\mathrm{SN}-6$ also affected parameters of flagellar movement (Fig. 7B, C, D, E, F and G). SN-6 $(50 \mu \mathrm{mol} / \mathrm{L})$ increased beat frequency at $0 \mathrm{~h}$ and caused earlier decrease at $1.5 \mathrm{~h}$ (Fig. 7B). It did not affect bend angles (sum of principal and reverse bends) when compared with $150 \mathrm{mmol} / \mathrm{L} \mathrm{NaCl} \mathrm{mTALP}$ (Fig. 7C), but increased reverse bend at $2 \mathrm{~h}$ when we looked at principal and reverse bends separately (Fig. 7D and E). Sliding velocity increased by $50 \mu \mathrm{mol} / \mathrm{L} \mathrm{SN}-6$ at $0 \mathrm{~h}$ incubation but was not affected by SN-6 at the other time of incubation (Fig. 7F). The waveform of activated spermatozoa (Fig. 7G a) and hyperactivated spermatozoa (Fig. 7G b) was apparently unaffected by $\mathrm{SN}-6$ in comparison with other conditions (Fig. 2F).
Amiloride, an inhibitor of epithelial $\mathrm{Na}^{+}$channel $(\mathrm{ENaC})$, had no effect on hyperactivation in the concentration range $0.1-20 \mathrm{mmol} / \mathrm{L}$ (Fig. 8).

\section{Tyrosine phosphorylations on fibrous sheath proteins were not changed by extracellular $\mathrm{Na}^{+}$}

The change in capacitation-associated tyrosine phosphorylation of fibrous sheath proteins by extracellular $\mathrm{Na}^{+}$was investigated by western blotting (Fig. 9 and Table 3). In standard mTALP that contains $101 \mathrm{mmol} / \mathrm{L} \mathrm{NaCl}$, time-dependent increase in the tyrosine phosphorylation on two major bands, which was likely to correspond with the 80 and $85 \mathrm{kDa}$ AKAPs, was observed (Fig. 9B arrowheads and Table 3). When extracellular $\mathrm{Na}^{+}$was decreased to $75 \mathrm{mmol} / \mathrm{L}$, no significant change of the density of 80 and $85 \mathrm{kDa}$ bands were observed compared with that in $101 \mathrm{mmol} / \mathrm{L} \mathrm{NaCl}$ (Fig. 9A and Table 3). Similarly, the density of 80 and 85 $\mathrm{kDa}$ bands from spermatozoa in $150 \mathrm{mmol} / \mathrm{L} \mathrm{NaCl}$ did not show significant change (Fig. $9 \mathrm{C}$ and Table 3). In addition, $50 \mu \mathrm{mol} / \mathrm{L} \mathrm{SN}-6$ in $150 \mathrm{mmol} / \mathrm{L} \mathrm{NaCl} \mathrm{mTALP}$ (Fig. 9E) did not cause marked change in the density of 80 and $85 \mathrm{kDa}$ bands when compared with those in $150 \mathrm{mmol} / \mathrm{L} \mathrm{NaCl}$ mTALP (Fig. 9C and Table 3) and $150 \mathrm{mmol} / \mathrm{L} \mathrm{NaCl} \mathrm{mTALP}+$ vehicle (Fig. 9D and Table 3).

\section{Discussion}

Hyperactivation is widely assumed to be necessary for the success of fertilization in vivo (Yanagimachi 1994, Quill et al. 2003, Ho et al. 2009). In addition, mammalian spermatozoa have to be hyperactivated in right timing, e.g. when ovum is ovulated into the ampulla of oviduct where fertilization occurs. It was previously proposed that the balance of facilitative factors and suppressive factors for hyperactivation controls the expression timing of hyperactivation. In contrast to the abundant knowledge on several facilitative factors for hyperactivation (Fujinoki 2008, 2011, Noguchi et al. 2008), however, there are few known suppressive factors for hyperactivation. Estrogen $17 \beta \mathrm{E}_{2}$ and GABA suppress the enhancement of hyperactivation by progesterone, but do not suppress hyperactivation itself (Fujinoki 2010, Kon et al. 2014). The proteins secreted from seminal vesicle, semenogelin in human sperm and SVS2 in mouse sperm, are known to act as a "decapacitation factor", but is unclear whether it affects hyperactivation or not (de Lamirande et al. 2001, Kawano \& Yoshida 2007). In this study, we discovered the suppressive or delaying factor of the hyperactivation for the first time, i.e., $\mathrm{Na}^{+}$. This study could be the important piece for the full understanding of the regulatory mechanisms of fertilization in vivo.

In this study, we first investigated the effect of osmotic pressure, and then we unexpectedly found 

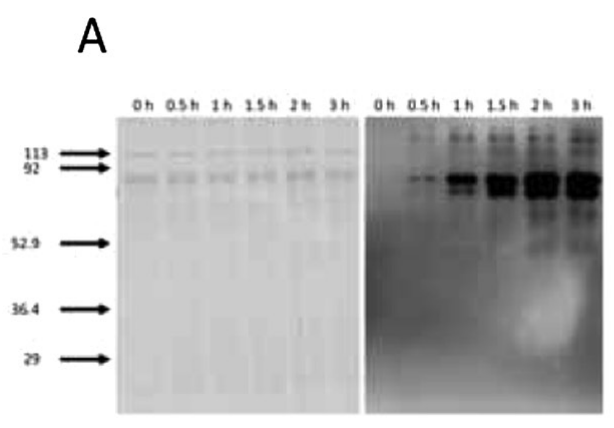

B

$\mathrm{C}$

D
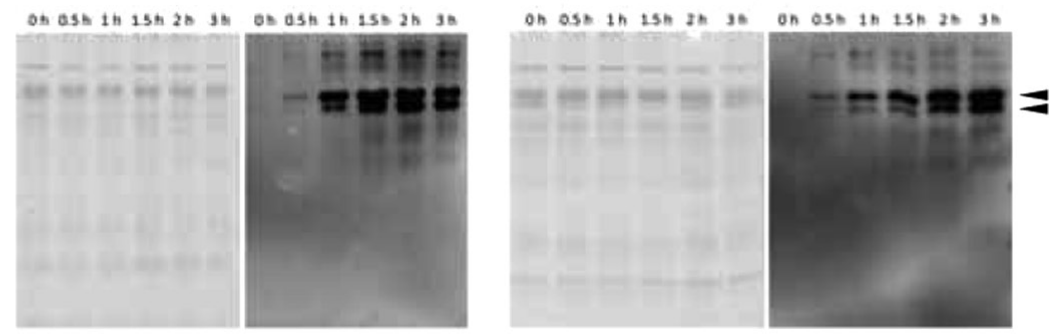

$E$
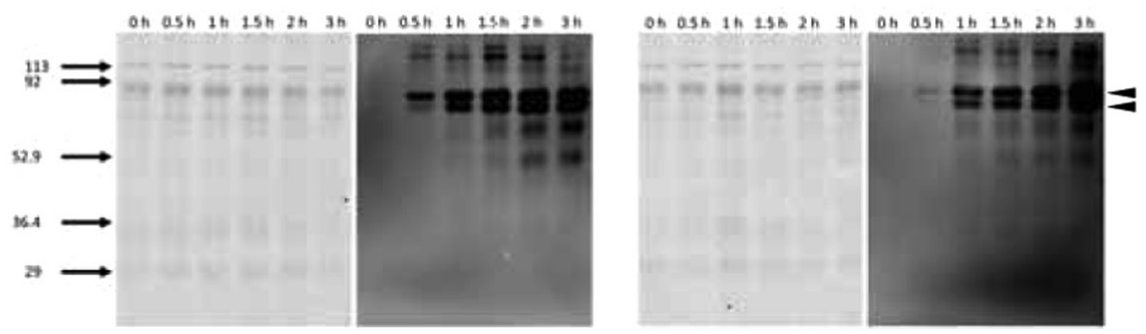

Figure 9 Tyrosine phosphorylation of hamster sperm fibrous sheath proteins. The time-course changes $(0,0.5,1,1.5,2$, and $3 \mathrm{~h})$ of tyrosine phosphorylation of hamster sperm fibrous sheath proteins in various conditions are shown. (A, B, C, D and E) Pictures of enhanced chemiluminescence (right panel) and CBB staining of the corresponding gel (left panel). (A) $75 \mathrm{mmol} / \mathrm{L} \mathrm{NaCl} \mathrm{mTALP}$. (B) $101 \mathrm{mmol} / \mathrm{L} \mathrm{mTALP}$. (C) $150 \mathrm{mmol} / \mathrm{L} \mathrm{mTALP}$. (D) $150 \mathrm{mmol} / \mathrm{L} \mathrm{mTALP}+$ vehicle. (E) $150 \mathrm{mmol} / \mathrm{L} \mathrm{mTALP}+50 \mu \mathrm{mol} / \mathrm{L} \mathrm{SN}-6$. Vehicle was ethanol and DMSO (1:1), and the final concentration was set to $0.1 \%$. The 85 and $80 \mathrm{kDa}$ AKAPs are indicated by arrowheads on the right side. The molecular sizes are shown on left side.

that extracellular $\mathrm{Na}^{+}$acts as a suppressive factor on hyperactivation (Figs 1 and 3). Osmotic environments did not affect hamster sperm motility or hyperactivation in the physiological range (Figs 1, 2 and 3). The effect of extracellular $\mathrm{Na}^{+}$on mouse sperm capacitation was reported previously (Fraser et al. 1993); however, the result was apparently contradictory. In the previous study, increase in extracellular $\mathrm{Na}^{+}$caused increase in AR pattern of chlortetracycline (CTC) staining in mouse spermatozoa, indicating that capacitation and acrosome reaction were promoted by $\mathrm{Na}^{+}$(Fraser et al. 1993). This contradiction might come from the difference of the aspect of capacitation-related event focused on hyperactivation in this study and the change of CTC staining in the previous study (Fraser et al.
1993). Spermatozoa are needed to be fixed before CTC staining, so the change of flagellar movement was unable to be assessed in the previous study (Fraser et al. 1993). Therefore, the effect of extracellular $\mathrm{Na}^{+}$ on hyperactivation might be overlooked in the previous study. In addition, difference of species used (hamster and mouse) may also affect the difference of results.

Extracellular $\mathrm{Na}^{+}$also affected the flagellar movement of hamster spermatozoa (Fig. 2). At the onset of incubation, activated hamster spermatozoa showed higher beat frequency and lower bend angles as the concentration of $\mathrm{NaCl}$ in mTALP increased (Fig. 2A and $\mathrm{B}$ ). Consequently, sliding velocity of the flagellum was significantly decreased as $\mathrm{NaCl}$ concentration of mTALP increased at $0,0.5$, and $1 \mathrm{~h}$ of incubation

Table 3 Densitometry of 85 and 80 kDa bands.

\begin{tabular}{|c|c|c|c|c|c|c|c|}
\hline & Hour & $\mathbf{0}$ & 0.5 & 1 & 1.5 & 2 & 3 \\
\hline \multirow[t]{5}{*}{$85 \mathrm{kDa}$} & 75 mmol/L NaCl mTALP & $0.139 \pm 0.133$ & $0.326 \pm 0.141$ & $1.043 \pm 0.135$ & $1.72 \pm 0.439$ & $1.77 \pm 0.329$ & $2.04 \pm 0.513$ \\
\hline & $101 \mathrm{mmol} / \mathrm{L} \mathrm{NaCl} \mathrm{mTALP}$ & $0.269 \pm 0.256$ & $0.422 \pm 0.119$ & $3.37 \pm 0.523$ & $4.74 \pm 0.916$ & $3.71 \pm 1.21$ & $4.44 \pm 2.08$ \\
\hline & $150 \mathrm{mmol} / \mathrm{L} \mathrm{NaCl} \mathrm{mTALP}$ & $0.082 \pm 0.063$ & $0.228 \pm 0.033$ & $1.09 \pm 0.052$ & $1.99 \pm 0.282$ & $2.26 \pm 0.284$ & $2.05 \pm 0.469$ \\
\hline & $150 \mathrm{mmol} / \mathrm{L} \mathrm{NaCl} \mathrm{mTALP}$ + vehicle & $0.195 \pm 0.083$ & $0.541 \pm 0.076$ & $2.14 \pm 0.537$ & $3.39 \pm 1.14$ & $3.01 \pm 0.944$ & $2.53 \pm 0.503$ \\
\hline & $\begin{array}{l}150 \mathrm{mmol} / \mathrm{L} \mathrm{NaCl} \\
\mathrm{mTALP}+50 \mu \mathrm{mol} / \mathrm{L} \mathrm{SN}-6\end{array}$ & $0.073 \pm 0.055$ & $0.159 \pm 0.068$ & $2.35 \pm 1.17$ & $2.60 \pm 1.16$ & $2.28 \pm 1.00$ & $3.07 \pm 1.43$ \\
\hline \multirow[t]{5}{*}{$80 \mathrm{kDa}$} & $75 \mathrm{mmol} / \mathrm{L} \mathrm{NaCl} \mathrm{mTALP}$ & $0.165 \pm 0.138$ & $0.114 \pm 0.082$ & $0.321 \pm 0.051$ & $0.707 \pm 0.243$ & $0.799 \pm 0.276$ & $1.20 \pm 0.343$ \\
\hline & $101 \mathrm{mmol} / \mathrm{L} \mathrm{NaCl} \mathrm{mTALP}$ & $0.272 \pm 0.211$ & $0.191 \pm 0.155$ & $1.23 \pm 0.152$ & $2.41 \pm 0.636$ & $2.55 \pm 0.829$ & $2.65 \pm 1.27$ \\
\hline & $150 \mathrm{mmol} / \mathrm{L} \mathrm{NaCl} \mathrm{mTALP}$ & $0.125 \pm 0.105$ & $0.044 \pm 0.004$ & $0.336 \pm 0.086$ & $0.765 \pm 0.175$ & $1.01 \pm 0.029$ & $1.30 \pm 0.152$ \\
\hline & $150 \mathrm{mmol} / \mathrm{L} \mathrm{NaCl} \mathrm{mTALP}$ + vehicle & $0.210 \pm 0.065$ & $0.0569 \pm 0.012$ & $1.06 \pm 0.191$ & $2.41 \pm 0.728$ & $2.39 \pm 0.672$ & $2.20 \pm 0.420$ \\
\hline & $\begin{array}{l}150 \mathrm{mmol} / \mathrm{L} \mathrm{NaCl} \\
\mathrm{mTALP}+50 \mu \mathrm{mol} / \mathrm{L} \mathrm{SN}-6\end{array}$ & $0.025 \pm 0.012$ & $0.0431 \pm 0.024$ & $1.28 \pm 0.620$ & $1.82 \pm 0.802$ & $1.55 \pm 0.649$ & $1.80 \pm 0.810$ \\
\hline
\end{tabular}

Data were expressed as the ratio to the density of the $50 \mathrm{kDa}$ band of marker Magic Marks. Data were expressed as mean of three membranes \pm S.E.M. Statistical analyses were done by one way ANOVA and Tukey-Kramer post hoc test, and there were no significant differences among them. 
(Fig. 2E). This decrease in sliding velocity directly led to the suppression of VCL (Fig. 1B). Bend angle as well as sliding velocity increased as incubation time progressed after $1.5 \mathrm{~h}$, and these increments seemed to be reflective of the increase in VCL (Figs 1B and 2B, E). These results suggest that not only hyperactivation but also activation, a vigorous motility at the beginning of incubation, of hamster spermatozoa was suppressed by extracellular $\mathrm{Na}^{+}$. In the previous study, it was reported that mouse sperm activation (swimming velocity and beat frequency) increased as the concentration of $\mathrm{NaCl}$ increased ( $\mathrm{Si}$ \& Okuno 1993). The regulation of hamster sperm beat frequency is likely to be regulated by $\mathrm{NaCl}$ in the same manner as mouse sperm. However, the results of swimming velocity were totally different. As the pattern of sperm flagellar movement (bending pattern and waveform) is quite different between mice and hamsters (Yanagimachi 1994), this contradiction might come from the difference of pattern of flagellar movement.

As incubation time progressed, beat frequency was gradually decreased, whereas bend angle and sliding velocity were gradually increased (Fig. $2 \mathrm{~A}, \mathrm{~B}$ and $\mathrm{E}$ ). At the same time, hyperactivation was gradually increased (Fig. 1C). Therefore, decrease of beat frequency and concomitant increase in bend angle are required for the expression of hyperactivated motility. At $2 \mathrm{~h}$ of incubation, the bend angle and beat frequency in $150 \mathrm{mmol} / \mathrm{L} \mathrm{NaCl} \mathrm{mTALP}$ was comparable to those in the other mTALPs (Fig. 2A and B). However, hyperactivation in $150 \mathrm{mmol} / \mathrm{L} \mathrm{NaCl} \mathrm{mTALP}$ was significantly lower at $2 \mathrm{~h}$ of incubation (Fig. 1C). Similarly, beat frequency, bend angle, and sliding velocity of SN-6-treated spermatozoa at $2 \mathrm{~h}$ showed no significant change to those in $150 \mathrm{mmol} / \mathrm{L} \mathrm{NaCl} \mathrm{mTALP}$, although hyperactivation at $2 \mathrm{~h}$ was significantly higher than vehicle (Figs 6C and $7 \mathrm{~B}, \mathrm{C}, \mathrm{F})$. When principal and reverse bends were considered separately, the principal bend at $2 \mathrm{~h}$ was unchanged among all conditions, whereas the reverse bend at $2 \mathrm{~h}$ was significantly lower in $150 \mathrm{mmol} / \mathrm{L} \mathrm{NaCl}$ mTALP (Figs 2C, D and 7D, E). These results indicate that an increase in reverse bend is necessary for the expression of hyperactivated motility. The parameters of hyperactivated sperm flagellar movement and waveform were unchanged by $\mathrm{NaCl}$ concentration and $\mathrm{SN}-6$, indicating that $\mathrm{NaCl}$ concentration or $\mathrm{SN}-6$ does not affect hyperactivation itself (Figs 2 and 7).

Seemingly, suppression of activation by $\mathrm{Na}^{+}$directly led to the delay in hyperactivation. However, bend angle and waveform of $\mathrm{SN}$-6-treated spermatozoa did not show remarkable change as $150 \mathrm{mmol} / \mathrm{L} \mathrm{NaCl} \mathrm{mTALP}$ at the onset of incubation, although they showed hyperactivation significantly earlier (Figs 6 and 7). These results suggest that although $\mathrm{Na}^{+}$concentration affected both hyperactivation and activation, regulatory mechanisms of them are different.

The $\mathrm{Na}$ concentration of oviductal fluid was $158.79 \pm 5.76 \mathrm{mmol} / \mathrm{L}$ (Table 2), similar to the $\mathrm{Na}^{+}$ concentration of $125 \mathrm{mmol} / \mathrm{L} \mathrm{NaCl} \mathrm{mTALP}$, which contains approximately $163 \mathrm{mmol} / \mathrm{L} \mathrm{Na}^{+}$. At this concentration, hyperactivation was slightly delayed compared with $101 \mathrm{mmol} / \mathrm{L} \mathrm{NaCl} \mathrm{mTALP}$ and was significantly delayed than that in $75 \mathrm{mmol} / \mathrm{L} \mathrm{NaCl}$ mTALP (Fig. 1C). These results suggest that oviductal environment is rather "suppressive" from the viewpoint of $\mathrm{Na}^{+}$concentration. It seems that the release from suppression by $\mathrm{Na}^{+}$plays an important role in the expression of hyperactivated motility. In fluids of male genitalia (seminal vesicle, prostate, and epididymis), Na concentration is low, which seems to facilitate hyperactivation (Table 2). In these fluids, however, concentrations of $\mathrm{K}$ and $\mathrm{Ca}$ are also quite different, so we are unable to conclude that seminal environment is facilitative or not. High concentration of $\mathrm{K}$ in prostatic fluid seems to be caused by destruction of cells upon collection (Table 2). However, determined concentration of $\mathrm{K}$ in hamster prostatic fluid was very close to that of human prostatic fluid collected by noninvasive way (Kavanagh 1985), so we assume that the way of collection of fluids affected minimum on determination of concentration.

When $\mathrm{Cl}^{-}$decreased by replacing it with gluconate-, hyperactivation was further delayed but not accelerated (Supplementary Figure 1). This suggests that delay of hyperactivation by increasing the concentration of $\mathrm{NaCl}$ was not caused by increase in $\mathrm{Cl}^{-}$. However, this result also suggests that $\mathrm{Cl}^{-}$also participates in the regulation of hyperactivation in hamster spermatozoa. However, decrease in $\mathrm{Na}^{+}$concentration by replacing it with choline ${ }^{+}$(or $\mathrm{NMDG}^{+}$) caused delay of hamster sperm hyperactivation more severely than decrease in $\mathrm{Cl}^{-}$(Supplementary Figures 1 and 2). These results suggest that the balance of $\mathrm{Na}^{+}$and $\mathrm{Cl}^{-}$plays a vital role in the regulation of hyperactivation, and $\mathrm{Na}^{+}$is more crucial than $\mathrm{Cl}^{-}$for hyperactivation.

In mouse spermatozoa, membrane potential is hyperpolarized during capacitation (Zeng et al. 1995), and such hyperpolarization is reported to be necessary for acrosome reaction (De La Vega-Beltran et al. 2012). In addition, capacitation-associated hyperpolarization is regulated by $\mathrm{Na}^{+}$conductance by $\mathrm{ENaC}$ (HernandezGonzalez et al. 2006, Escoffier et al. 2012). In contrast to these facts, hamster sperm membrane potentials were not changed by extracellular $\mathrm{Na}^{+}$concentration (Fig. 4A). In addition, amiloride, an inhibitor of $\mathrm{ENaC}$, did not affect hamster sperm hyperactivation (Fig. 8), suggesting that membrane potential is not involved in the regulation of hyperactivation by $\mathrm{Na}^{+}$. These results mean that the characteristics of spermatozoa are quite different even in hamsters and mice from the viewpoint of membrane potential.

Generally, $\mathrm{pH}_{\mathrm{i}}$ increases during capacitation (Zeng et al. 1996, Nakanishi et al. 2001). In addition, $\mathrm{Na}^{+}-$ $\mathrm{HCO}_{3}{ }^{-}$cotransporter (NBC) and $\mathrm{Na}^{+}-\mathrm{H}^{+}$exchanger (NHE) are reported to be involved in capacitation and fertilization (Demarco et al. 2003, Wang et al. 2003). 
These reports led us to think that modulation of $\mathrm{pH}_{\mathrm{i}}$ according to the concentration of extracellular $\mathrm{Na}^{+}$ could be a cause of delay of hyperactivation. However, whole-cell $\mathrm{pH}_{\mathrm{i}}$ value and $\mathrm{pH}_{\mathrm{i}}$ geometry were not affected by change in extracellular $\mathrm{Na}^{+}$concentration (Fig. 4B, C and Supplementary Figure 3), suggesting that $\mathrm{pH}_{\mathrm{i}}$ is not involved in the regulation of hyperactivation by $\mathrm{Na}^{+}$.

Finally, we found that hamster sperm $\left[\mathrm{Ca}^{2+}\right]_{i}$ decreased as the extracellular $\mathrm{Na}^{+}$concentration increased especially at midpiece and principal piece (Fig. 5) and that the NCX inhibitors canceled the effect of extracellular $\mathrm{Na}^{+}$on hamster sperm hyperactivation (Figs 6 and 7A). These results indicate that the extracellular $\mathrm{Na}^{+}$suppresses hyperactivation by lowering $\left[\mathrm{Ca}^{2+}\right]_{i}$ presumably in the flagellum via an action of NCX. This suggests that hyperactivation is suppressed by NCX before capacitation, and the inhibition of NCX activity is necessary to be hyperactivated.

In this study, we have not found the NCXs in hamster spermatozoa yet. However, the activity of $\mathrm{Na}^{+}$-dependent $\mathrm{Ca}^{2+}$ extrusion was shown in mouse spermatozoa (Wennemuth et al. 2003). In addition, the existence of NCX in the flagellum and its function in spermatozoa were previously reported in Ciona (Shiba et al. 2006), human (Krasznai et al. 2006), and herring (Vines et al. 2002). The existence of $\mathrm{K}^{+}$-dependent $\mathrm{Na}^{+}-\mathrm{Ca}^{2+}$ exchanger (NCKX), an another transporter that has activity to exchanger $\mathrm{Na}^{+}$and $\mathrm{Ca}^{2+}$ across the plasma membrane, in sea urchin spermatozoa have also been shown (Su \& Vacquier 2002). These facts support the idea that NCX is present and functional in hamster spermatozoa. In those previous studies, however, full-length NCX was not (or only slightly) detected by western blotting (Krasznai et al. 2006, Shiba et al. 2006). In addition, it was discussed that the NCX in herring spermatozoa operate in reverse mode $\left(\mathrm{Ca}^{2+}\right.$ influx), and NCX in Ciona spermatozoa contribute to $\left[\mathrm{Ca}^{2+}\right]_{i}$ transient (Vines et al. 2002, Shiba et al. 2006). In sea (or brackish) water environment where herring or Ciona spawn, $\mathrm{Na}^{+}$exists at high concentration, which should exclusively cause efflux of intracellular $\mathrm{Ca}^{2+}$. Furthermore, previous studies used KB-R7943, $3^{\prime}, 4^{\prime}$-dichlorobenzamil hydrochloride (DCB), and bepridil as NCX inhibitor, which have rather lower specificity to NCX than SEA0400 and SN-6 (Matsuda et al. 2001, Iwamoto et al. 2004). Actually, $50 \mu \mathrm{mol} / \mathrm{L}$ KB-R7943 significantly decreased the percentage of motile spermatozoa (Supplementary Figure 5A), indicating harmful side effect. Taken together, the precise physiological role of NCX in spermatozoa is still controversial, and thus, further studies are needed to elucidate which type of NCX (or NCKX) is involved in the regulation of hamster sperm capacitation.

The concentration of SN-6 and SEA0400 used in this study $(50 \mu \mathrm{mol} / \mathrm{L})$ was rather high because forward mode of $\mathrm{NCX}\left(\mathrm{Ca}^{2+}\right.$ extrusion) is less sensitive to these inhibitors than reverse mode $\left(\mathrm{Ca}^{2+}\right.$ influx) (Iwamoto et al. 2004, Lee et al. 2004). However, we assume that concentrations of these inhibitors does not matter as the percentage of motile spermatozoa was not affected by these concentrations (Fig. 6A and D), in contrast to KB-R7943 (Supplementary Figure 5A).

It is widely accepted that the tyrosine phosphorylation is strongly associated with capacitation (Visconti et al. 1995, 1998, Visconti \& Kopf 1998). Especially, tyrosine phosphorylation on AKAPs of fibrous sheath during capacitation was widely observed in human and hamster spermatozoa (Carrera et al. 1996, Jha \& Shivaji 2002). In this study, tyrosine phosphorylation on two major bands, which was likely to correspond with the 80 and 85 kDa AKAPs respectively, was observed among all samples and no significant change was seen among them (Fig. 9A, B, C, D, E and Table 3). These results suggest that a well-known tyrosine phosphorylationdependent signaling pathway of capacitation progressed normally regardless of extracellular $\mathrm{Na}^{+}$concentration. However, hyperactivation was delayed as extracellular $\mathrm{Na}^{+}$concentration increased (Figs 1 and 3), suggesting that hyperactivation was controlled by the other pathway, which is independent of the conventional tyrosine phosphorylation-dependent pathway in our experimental condition. Recent study showed that mouse sperm hyperactivation could be induced by transient $\left[\mathrm{Ca}^{2+}\right]_{\mathrm{i}}$ increase by ionophore without activation of cAMP-dependent tyrosine phosphorylation pathways (Tateno et al. 2013). In this study, we showed that hamster sperm $\left[\mathrm{Ca}^{2+}\right]_{\mathrm{i}}$ increased when extracellular $\mathrm{Na}^{+}$decreased, presumably because of decline of NCX activity by decrease in extracellular $\mathrm{Na}^{+}$(Figs 6 and $7 A)$. Indeed, it was previously shown that the inward NCX current (i.e., $\mathrm{Ca}^{2+}$ efflux) was changed depending on the external $\mathrm{Na}^{+}$concentration in the range close to our experimental conditions $\left(0-150 \mathrm{mmol} / \mathrm{L} \mathrm{Na}^{+}\right)$ in rat odontoblasts (Tsumura et al. 2010). Collectively, it is suggested that hamster sperm hyperactivation could be regulated by $\mathrm{Ca}^{2+}$-dependent and tyrosine phosphorylation-independent pathway simultaneously with tyrosine phosphorylation-dependent pathway such as mouse sperm, and such $\mathrm{Ca}^{2+}$-dependent and tyrosine phosphorylation-independent pathway may lead to hyperactivation when extracellular $\mathrm{Na}^{+}$concentration decreased. Otherwise, calmodulin-dependent kinase (CaM kinase)-dependent phosphorylation, which was shown in mouse spermatozoa (Schlingmann et al. 2007), may act as modulatory pathway for hyperactivation in hamster spermatozoa.

In conclusion, this study showed that hamster sperm hyperactivation is altered by extracellular $\mathrm{Na}^{+}$concentration. Extracellular $\mathrm{Na}^{+}$suppresses sperm activation and hyperactivation, and the removal of suppression by extracellular $\mathrm{Na}^{+}$leads to the expression of hyperactivated motility. This suppression of hyperactivation is suggested to be regulated via an action of NCX. 


\section{Supplementary data}

This is linked to the online version of the paper at http://dx.doi. org/10.1530/REP-15-0367.

\section{Declaration of interest}

The authors declare that there is no conflict of interest that could be perceived as prejudicing the impartiality of this work.

\section{Funding}

This work was supported by Dokkyo Medical University, Investigator-Initiated Research Grant (No. 2013-03). This work was also supported by JSPS KAKENHI Grant number 15K21323.

\section{Acknowledgements}

The authors thank Dr Yoshio Takei of Laboratory of Physiology, Department of Biological Sciences, Atmosphere and Ocean Research Institute, The University of Tokyo, for kindly providing us an atomic absorption supectrophotometer. They also thank Dr Hiroyuki Sugimoto and Dr Chieko Aoyama of Department of Biochemistry, Dokkyo Medical University, for providing us spectrophotometer.

\section{References}

Alasmari W, Barratt C, Publicover S, Whalley K, Foster E, Kay V, da Silva S \& Oxenham S 2013 The clinical significance of calciumsignalling pathways mediating human sperm hyperactivation. Human Reproduction 28 866-876. (doi:10.1093/humrep/des467)

Alavi S \& Cosson J 2006 Sperm motility in fishes. (II) Effects of ions and osmolality: a review. Cell Biology International 30 1-14. (doi:10.1016/j. cellbi.2005.06.004)

Armon L \& Eisenbach M 2011 Behavioral mechanism during human sperm chemotaxis: involvement of hyperactivation. PLOS ONE 6 e28359.

Baldi E, Luconi M, Muratori M, Marchiani S, Tamburrino L \& Forti G 2009 Nongenomic activation of spermatozoa by steroid hormones: facts and fictions. Molecular and Cellular Endocrinology 308 39-46. (doi:10.1016/j.mce.2009.02.006)

Calogero A, Hall J, Fishel S, Green S, Hunter A \& D'Agata R 1996 Effects of $\gamma$-aminobutyric acid on human sperm motility and hyperactivation. Molecular Human Reproduction 2 733-738. (doi:10.1093/ molehr/2.10.733)

Carrera A, Moos J, Ning X, Gerton G, Tesarik J, Kopf G \& Moss S 1996 Regulation of protein tyrosine phosphorylation in human sperm by a calcium/calmodulin-dependent mechanism: identification of a kinase anchor proteins as major substrates for tyrosine phosphorylation. Developmental Biology 180 284-296. (doi:10.1006/dbio.1996.0301)

Chen Q \& Duan E 2011 Aquaporins in sperm osmoadaptation: an emerging role for volume regulation. Acta Pharmacologica Sinica 32 721-724. (doi:10.1038/aps.2011.35)

Chen Q, Peng H, Lei L, Zhang Y, Kuang H, Cao Y, Shi Q, Ma T \& Duan E 2011 Aquaporin3 is a sperm water channel essential for postcopulatory sperm osmoadaptation and migration. Cell Research 21 922-933. (doi:10.1038/cr.2010.169)

Coy P, Garcia-Vazquez F, Visconti P \& Aviles M 2012 Roles of the oviduct in mammalian fertilization. Reproduction 144 649-660. (doi:10.1530/ REP-12-0279)

De La Vega-Beltran J, Sanchez-Cardenas C, Krapf D, HernandezGonzalez E, Wertheimer E, Trevino C, Visconti P \& Darszon A 2012 Mouse sperm membrane potential hyperpolarization is necessary and sufficient to prepare sperm for the acrosome reaction. Journal of Biological Chemistry 287 44384-44393. (doi:10.1074/jbc.M112.393488)
De Lamirande E, Yoshida K, Yoshiike M, Iwamoto T \& Gagnon C 2001 Semenogelin, the main protein of semen coagulum, inhibits human sperm capacitation by interfering with the superoxide anion generated during this process. Journal of Andrology 22 672-679.

de las Heras M, Valcarcel A \& Perez L 1997 In vitro capacitating effect of gamma-aminobutyric acid in ram spermatozoa. Biology of Reproduction 56 964-968.

Demarco I, Espinosa F, Edwards J, Sosnik J, de la Vega-Beltran J, Hockensmith J, Kopf G, Darszon A \& Visconti P 2003 Involvement of a $\mathrm{Na}^{+} / \mathrm{HCO}^{3}$ cotransporter in mouse sperm capacitation. Journal of Biological Chemistry 278 7001-7009. (doi:10.1074/jbc.M206284200)

du Plessis S, Hagenaar K \& Lampiao F 2010 The in vitro effects of melatonin on human sperm function and its scavenging activities on NO and ROS. Andrologia 42 112-116. (doi:10.1111/and.2010.42.issue-2)

Escoffier J, Krapf D, Navarrete F, Darszon A \& Visconti P 2012 Flow cytometry analysis reveals a decrease in intracellular sodium during sperm capacitation. Journal of Cell Science 125 473-485. (doi:10.1242/ jcs.093344)

Espinosa F \& Darszon A 1995 Mouse sperm membrane-potential - changes induced by $\mathrm{Ca}^{2+}$. FEBS Letters 372 119-125. (doi:10.1016/00145793(95)00962-9)

Fraser L, Umar G \& Sayed S $1993 \mathrm{Na}^{+}$-requiring mechanisms modulate capacitation and acrosomal exocytosis in mouse spermatozoa. Journal of Reproduction and Fertility 97 539-549. (doi:10.1530/ jrf.0.0970539)

Fujinoki M 2008 Melatonin-enhanced hyperactivation of hamster sperm. Reproduction 136 533-541. (doi:10.1530/REP-08-0202)

Fujinoki M 2009 Non genomic regulation of mammalian sperm hyperactivation. Reproductive Medicine and Biology 8 47-52. (doi:10.1007/s12522-009-0012-2)

Fujinoki M 2010 Suppression of progesterone-enhanced hyperactivation in hamster spermatozoa by estrogen. Reproduction 140 453-464. (doi:10.1530/REP-10-0168)

Fujinoki M 2011 Serotonin-enhanced hyperactivation of hamster sperm. Reproduction 142 255-266. (doi:10.1530/REP-11-0074)

Fujinoki M 2014 Regulation and disruption of hamster sperm hyperactivation by progesterone, 17 $\beta$-estradiol and diethylstilbestrol. Reproductive Medicine and Biology 13 143-152. (doi:10.1007/s12522013-0175-8)

Fujinoki M \& Takei G 2015 Estrogen suppresses melatonin-enhanced hyperactivation of hamster spermatozoa. Journal of Reproduction and Development 61 287-295. (doi:10.1262/jrd.2014-116)

Fujinoki M, Ohtake H \& Okuno M 2001 Serine phosphorylation of flagellar proteins associated with the motility activation of hamster spermatozoa. Biomedical Research-Tokyo 22 45-58. (doi:10.2220/biomedres.22.45)

Fujinoki M, Suzuki T, Takayama T, Shibahara H \& Ohtake H 2006 Profiling of proteins phosphorylated or dephosphorylated during hyperactivation via activation on hamster spermatozoa. Reproductive Medicine and Biology 5 123-135.

Fujinoki M, Takei G \& Kon H 2016 Non-genomic regulation and disruption of spermatozoal in vitro hyperactivation by oviductal hormones. Journal of Physiological Sciences 66 207-212. (doi:10.1007/s12576-015-0419-y)

Hernandez-Gonzalez E, Sosnik J, Edwards J, Acevedo J, MendozaLujambio I, Lopez-Gonzalez I, Demarco I, Wertheimer E, Darszon A \& Visconti P 2006 Sodium and epithelial sodium channels participate in the regulation of the capacitation-associated hyperpolarization in mouse sperm. Journal of Biological Chemistry 281 5623-5633.

Ho K, Wolff C \& Suarez S 2009 CatSper-null mutant spermatozoa are unable to ascend beyond the oviductal reservoir. Reproduction Fertility and Development 21 345-350. (doi:10.1071/RD08183)

Iwamoto T, Inoue Y, Ito K, Sakaue T, Kita S \& Katsuragi T 2004 The exchanger inhibitory peptide region-dependent inhibition of $\mathrm{Na}^{+} /$ $\mathrm{Ca}^{2+}$ exchange by SN-6 [2-[4-(4-nitrobenzyloxy)benzyl]thiazolidine4-carboxylic acid ethyl ester], a novel benzyloxyphenyl derivative. Molecular Pharmacology 66 45-55. (doi:10.1124/mol.66.1.45)

Izumi H, Marian T, Inaba K, Oka Y \& Morisawa M 1999 Membrane hyperpolarization by sperm-activating and -attracting factor increases cAMP level and activates sperm motility in the ascidian Ciona intestinalis. Developmental Biology 213 246-256. (doi:10.1006/dbio.1999.9367)

Jha K \& Shivaji S 2002 Identification of the major tyrosine phosphorylated protein of capacitated hamster spermatozoa as a homologue of mammalian sperm a kinase anchoring protein. Molecular Reproduction and Development 61 258-270. (doi:10.1002/(ISSN)1098-2795) 
Kavanagh J 1985 Sodium, potassium, calcium, magnesium, zinc, citrate and chloride content of human prostatic and seminal fluid. Journal of Reproduction and Fertility 75 35-41. (doi:10.1530/jrf.0.0750035)

Kawano N \& Yoshida M 2007 Semen-coagulating protein, SVS2, in mouse seminal plasma controls sperm fertility. Biology of Reproduction $\mathbf{7 6}$ 353-361.

Kon H, Takei G, Fujinoki M \& Shinoda M 2014 Suppression of progesterone-enhanced hyperactivation in hamster spermatozoa by gamma-aminobutyric acid. Journal of Reproduction and Development 60 202-209. (doi:10.1262/jrd.2013-076)

Krasznai Z, Krasznai Z, Morisawa M, Bazsane Z, Hernadi Z, Fazekas Z, Tron L, Goda K \& Marian T 2006 Role of the $\mathrm{Na}^{+} / \mathrm{Ca}^{2+}$ exchanger in calcium homeostasis and human sperm motility regulation. Cell Motility and the Cytoskeleton 63 66-76. (doi:10.1002/(ISSN)1097-0169)

Laemmli U 1970 Cleavage of structural proteins during the assembly of the head of bacteriophageT4. Nature 227 680-685. (doi:10.1038/227680a0)

Lee C, Visen N, Dhalla N, Le $\mathbf{H}$, Isaac $M$, Choptiany P, Gross G, Omelchenko A, Matsuda T, Baba A et al. 2004 Inhibitory profile of SEA0400 [2-[4-[(2,5-difluorophenyl)methoxy]phenoxy]-5ethoxyaniline] assessed on the cardiac $\mathrm{Na}^{+}-\mathrm{Ca}^{2+}$ exchanger, NCX1.1. Journal of Pharmacology and Experimental Therapeutics 311 748-757. (doi:10.1124/jpet.104.070805)

Libersky E \& Boatman D 1995 Progesterone concentrations in serum, follicular - fluid, and oviductal fluid of the golden-hamster during the periovulatory period. Biology of Reproduction 53 477-482. (doi:10.1095/biolreprod53.3.477)

Louzan P, Gallardo M \& Tramezzani J 1986 Gamma-aminobutyric acid in the genital tract of the rat during the oestrous cycle. Journal of Reproduction and Fertility 77 499-504. (doi:10.1530/jrf.0.0770499)

Maleszewski M, Kline D \& Yanagimachi R 1995 Activation of hamster zonafree oocytes by homologous and heterologous spermatozoa. Journal of Reproduction and Fertility 105 99-107. (doi:10.1530/jrf.0.1050099)

Matsuda T, Arakawa N, Takuma K, Kishida Y, Kawasaki Y, Sakaue M, Takahashi K, Takahashi T, Suzuki T, Ota T et al. 2001 SEA0400, a novel and selective inhibitor of the $\mathrm{Na}^{+}-\mathrm{Ca}^{2+}$ exchanger, attenuates reperfusion injury in the in vitro and in vivo cerebral ischemic models. Journal of Pharmacology and Experimental Therapeutics 298 249-256.

Nakanishi T, Ikawa M, Yamada S, Toshimori K \& Okabe M 2001 Alkalinization of acrosome measured by GFP as a $\mathrm{pH}$ indicator and its relation to sperm capacitation. Developmental Biology 237 222-231. (doi:10.1006/dbio.2001.0353)

Negulescu T \& Machen T 1990 Intracellular ion activities and membrane transport in parietal cells measured with fluorescent dyes. In Methods in Enzymology, vol 192, pp 38-81. New York, NY, USA: Academic Press Inc.

Noguchi T, Fujinoki M, Kitazawa M \& Inaba N 2008 Regulation of hyperactivation of hamster spermatozoa by progesterone. Reproductive Medicine and Biology 7 63-74. (doi:10.1111/j.14470578.2008.00202.x)

Quill T, Sugden S, Rossi K, Doolittle L, Hammer R \& Garbers D 2003 Hyperactivated sperm motility driven by CatSper2 is required for fertilization. PNAS 100 14869-14874. (doi:10.1073/ pnas.2136654100)

Ritta M, Calamera J \& Bas D 1998 Occurrence of GABA and GABA receptors in human spermatozoa. Molecular Human Reproduction 4 769-773. (doi:10.1093/molehr/4.8.769)

Schillo K 2009 Reproductive Physiology of Mammals: From Farm to Field and Beyond. New York, NY, USA: Delmer Press.

Schlingmann K, Michaut M, Mcelwee J, Wolff C, Travis A \& Turner R 2007 Calmodulin and CaMKII in the sperm principal piece: evidence for a motility-related Calcium/Calmodulin pathway. Journal of Andrology 28 706-716. (doi:10.2164/jandrol.106.001669)

Shiba K, Marian T, Krasznai Z, Baba S, Morisawa M \& Yoshida M $2006 \mathrm{Na}^{+} / \mathrm{Ca}^{2+}$ exchanger modulates the flagellar wave pattern for the regulation of motility activation and chemotaxis in the ascidian spermatozoa. Cell Motility and the Cytoskeleton 63 623-632. (doi:10.1002/cm.20149)

Si Y \& Okuno M 1993 Multiple activation of mouse sperm motility. Molecular Reproduction and Development 36 89-95. (doi:10.1002/ mrd.1080360113)
Su Y \& Vacquier V 2002 A flagellar $\mathrm{K}^{+}$-dependent $\mathrm{Na}^{+} / \mathrm{Ca}^{2+}$ exchanger keeps $\mathrm{Ca}^{2+}$ low in sea urchin spermatozoa. PNAS 99 6743-6748. (doi:10.1073/pnas.102186699)

Takai H \& Morisawa M 1995 Change in intracellular $\mathrm{K}^{+}$concentration caused by external osmolality change regulates sperm motility of marine and fresh-water teleosts. Journal of Cell Science 108 1175-1181.

Takei G, Mukai C \& Okuno M 2012 Transient $\mathrm{Ca}^{2+}$ mobilization caused by osmotic shock initiates salmonid fish sperm motility. Journal of Experimental Biology 215 630-641. (doi:10.1242/jeb.063628)

Takei G, Miyashiro D, Mukai C \& Okuno M 2014 Glycolysis plays an important role in energy transfer from the base to the distal end of the flagellum in mouse sperm. Journal of Experimental Biology 217 18761886. (doi:10.1242/jeb.090985)

Takei G, Mukai C \& Okuno M 2015 Regulation of salmonid fish sperm motility by osmotic shock-induced water influx across the plasma membrane. Comparative Biochemistry and Physiology Part A: Molecular \& Integrative Physiology 182 84-92.

Tateno H, Krapf D, Hino T, Sanchez-Cardenas C, Darszon A, Yanagimachi R \& Visconti P 2013 Ca $^{2+}$ ionophore A23187 can make mouse spermatozoa capable of fertilizing in vitro without activation of cAMP-dependent phosphorylation pathways. PNAS $11018543-18548$. (doi:10.1073/pnas.1317113110)

Tsumura M, Okumura R, Tatsuyama S, Ichikawa H, Muramatsu T, Matsuda T, Baba A, Suzuki K, Kajiya H, Sahara Y et al. $2010 \mathrm{Ca}^{2+}$ extrusion via $\mathrm{Na}^{+}-\mathrm{Ca}^{2+}$ exchangers in rat odontoblasts. Journal of Endodontics 36 668-674. (doi:10.1016/j.joen.2010.01.006)

Uto N \& Yamahama Y 1996 The motility and fertility of golden hamster sperm cultured in BSA-free medium. Biology of the Cell 88 23-28. (doi:10.1016/S0248-4900(97)86827-X)

Vines C, Yoshida K, Griffin F, Pillai M, Morisawa M, Yanagimachi R \& Cherr G 2002 Motility initiation in herring sperm is regulated by reverse sodium-calcium exchange. PNAS 99 2026-2031. (doi:10.1073/ pnas.042700899)

Visconti P \& Kopf G 1998 Regulation of protein phosphorylation during sperm capacitation. Biology of Reproduction 59 1-6. (doi:10.1095/ biolreprod59.1.1)

Visconti P, Bailey J, Moore G, Pan D, Oldsclarke P \& Kopf G 1995 Capacitation of mouse spermatozoa. I. Correlation between the capacitation state and protein-tyrosine phosphorylation. Development 121 1129-1137.

Visconti P, Galantino-Homer H, Moore G, Bailey J, Ning X, Fornes M \& Kopf G 1998 The molecular basis of sperm capacitation. Journal of Andrology 19 242-248.

Wang D, King S, Quill T, Doolittle L \& Garbers D 2003 A new spermspecific $\mathrm{Na}^{+} / \mathrm{H}^{+}$exchanger required for sperm motility and fertility. Nature Cell Biology 5 1117-1122. (doi:10.1038/ncb1072)

Wennemuth G, Babcock D \& Hille B 2003 Calcium clearance mechanisms of mouse sperm. Journal of General Physiology 122 115-128. (doi:10.1085/jgp.200308839)

Yanagimachi R 1994 Mammalian fertilization. In The Physiology of Reproduction, edn 2, pp 189-317. Eds E Knobil \& J Neil. New York, NY, USA: Raven Press.

Yeung C, Barfield J \& Cooper T 2006 Physiological volume regulation by spermatozoa. Molecular and Cellular Endocrinology 250 98-105. (doi:10.1016/j.mce.2005.12.030)

Zeng Y, Clark E \& Florman H 1995 Sperm membrane-potential hyperpolarization during capacitation regulates zona pellucidadependent acrosomal secretion. Developmental Biology 171 554-563. (doi:10.1006/dbio.1995.1304)

Zeng Y, Oberdorf J \& Florman H $1996 \mathrm{pH}$ regulation in mouse sperm: identification of $\mathrm{Na}^{+}-\mathrm{Cl}^{-}$, and $\mathrm{HCO}_{3}{ }^{-}$dependent and arylaminobenzoatedependent regulatory mechanisms and characterization of their roles in sperm capacitation. Developmental Biology 173 510-520.

Received 16 August 2015

First decision 16 September 2015

Revised manuscript received 26 February 2016

Accepted 7 March 2016 